\title{
IMPROVING FRUIT QUALITY AND EARLINESS OF MANFALOUTY POMEGRANATE BY USING SOME DORMANCY BREAKING AGENTS.
}

\author{
(Received 13-11-2017)
}

\author{
By \\ A.T. Abo-El-Ez, T.Kh. El-Boolk ${ }^{*}$ and M. A. Hassan* \\ Horticulture Department Faculty of Agriculture Sohag University, Sohag, Egypt. \\ * Department of olive, Horticulture Research Institute, Agricultural Research Center, Giza, Egypt.
}

\begin{abstract}
The present study was carried out during two successive seasons of 2014 and 2015 on Manfalouty pomegranate trees grown in a private orchard, situated at Arab-Elawamer region, Abnoub city, Assiut Government, Egypt. The trees 9-years-old, were grown in sandy soil at $5 \times 5 \mathrm{~m}$ apart and irrigated by drip irrigation system. The main objective of this investigation was to study the effect of dormancy breaking agent on vegetative growth and flower bud breaking for producing early, high quality and increasing in grain crop of Manfalouty pomegranate cultivar. Considered dormancy breaking agent were mineral winter oil (MO) and Hydrogen cyanamide $\left(\mathrm{H}_{2} \mathrm{CN}_{2}\right)$ (H.C.). Winter oil (MO) was as applied one concentration (3\%), while hydrogen cyanamide (H.C.) at three different concentrations (1.5 or 3.0 or $4.5 \%$ ) and their combinations. All treatments were added at as foliar sprays three different dates $\left(1^{\text {st }} \mathrm{Jan}\right.$. or $15 \mathrm{Jan}$. or $1^{\text {st }} \mathrm{Feb}$.). The aim of this study was to formulate a general recommendation to be used by pomegranate growers for enhancing budburst, yield and fruit quality under Assiut governorate climatic conditions. The results showed significant variation in the bud burst percentage, fruit yield, fruits weight, fruit grain weight, fruit juice and total anthothianin percentage in aril and rind. The increase in total soluble solids (TSS) percentage, and Vitamin C content in fruit juice were obtained by application of winter mineral oil plus Hydrogen cyanamide (MO $3 \%+$ H.C. $4.5 \%$ ) on $1^{\text {st }}$ January. Thus, it can be recommended the application of winter mineral oil plus Hydrogen cyanamide (MO $3 \%+$ H.C. $4.5 \%$ ) on $1^{\text {st }}$ January which could be a suitable technology for producing early and high quality of Manfalouty pomegranate fruits under Assiut governorate climatic conditions. This treatment is recommended for Manfalouty pomegranate growers in this area.
\end{abstract}

Key words: Manfalouty pomegranate, Hydrogen cyanamide, winter oil, Assiut Government.

\section{INTRODUCTION}

Pomegranate is mainly grown in tropical and subtropical areas of the world. High quality fruits can be produced where there is cool winter and worm hot dry summer. (Melgarejo et al., 2009, Ozguuven et al., 2009 and Sawarsan et al., 2011). The optimal temperature for fruit development is about $30-35^{\circ} \mathrm{C}$. The tree cannot produce sweet fruits unless the temperature is high for a sufficiently long period. The quality of fruit is adversely affected in humid climate. It is successfully grown in Upper Egypt, especially in Assiut region which occupies the first ranks of area and production (Abdel All, 2007). There is a major problem in the cultivation of most deciduous fruit trees in Egypt, which is the lack of chilling needed to break bud dormancy. Spraying with dormancy breaking agents break the bud dormancy was suggested (Doorenbos, 1953). However, there are two main purposes of using rest breaking agents, improving level of bud breaking and advancing bloom and vegetative bud development (Erez et al., 1993). Hydrogen cyanimide and mineral oil are dormancy breaking agents used widely to break bud dormancy (Georg et al., 1988 and Haggag et al., 1999).

In view of these facts, an attempt was made to see the response to mineral oil and Hydrogen cyanamide on defoliation and twig bud sprouting in pomegranate. Thus, the main objective of this investigation was to study the effect of some chemicals on the vegetative and flower bud break, to produc early and high quality fruits Manfalouty pomegranate cultivar. Through the application of dormancy breaking chemicals such as mineral oil and Hydrogen cyanamide $\left(\mathrm{H}_{2} \mathrm{CN}_{2}\right)$ alone, or in combination with different timing, in order to formulate a general recommendation to be used by pomegranate 
growers to enhance bud break, yield and fruit quality under Assiut climatic conditions.

\section{MATERIALS AND METHODS}

The present study was carried out during two successive seasons of 2014 and 2015 on Manfalouty pomegranate trees grown in a private orchard, situated at Arab-Elawamer region, Abnoub city, Assiut Government, Egypt. The pomegranate trees were propagated by hardwood cuttings. The trees are about 9- years old when this study started, grown in a sandy soil $5 \times 5 \mathrm{~m}$ apart. The selected trees were uniform in vigour, size and of normal growth. All the chosen pomegranate trees received regular horticultural practices that were carried out in the pomegranate orchards, and irrigated by drip irrigation system. These common practices included pruning, hoeing, pest and fungi control management. Fertilization with farmyard manure, ammonium sulphate $(20.6 \% \quad \mathrm{~N})$, calcium superphosphate $\left(\begin{array}{lll}15.5 \% & \mathrm{P}_{2} & \mathrm{O}_{5}\end{array}\right)$ and potassium sulphate $\left(48 \% \quad \mathrm{~K}_{2} \mathrm{O}\right)$ were added as recommended by the Ministry of Agricultural. Maximum and minimum temperatures and relative humidity for Arab-Elawamer region (Experimental location) during the two experimental seasons (according to Metrology Organization in Cairo) are shown in Table (1).

\subsection{Experimental Work}

After winter pruning, two dormancy breaking compounds, namely mineral oil (MO) and Hydrogen cyanamide " $49 \% \mathrm{H}_{2} \mathrm{CN}_{2}$ " were applied alone or in combination at any of the following time, on the first of January, mid- January, on the first of February at dormant bud stage using a hand driven sprayer (atomizer), and irrigation was done after spray. The control treatment was (water plus Tween 20 "1\%") on Manfalouty cv. during 2014 and 2015 seasons. The treatments were mineral oil $(3 \%)$, Hydrogen cyanamide $(1.5 \%, 3 \%$ and $4.5 \%)$ and mineral oil + Hydrogen cyanamide (combination). Each tree was sprayed completely with about $200 \mathrm{ml}$ of the solution which was sufficient to "drip point" using a hand driven sprayer. Wetting agent Tween $20(1 \%)$ was applied with the spraying solution.

\subsection{The treatments}

- (T1) Control (water plus Tween 20 "1\%").

- (T2) Spraying by Mineral Oil 3\% on $1^{\text {st }}$ Jan., $15^{\text {th }}$ Jan. and the $1^{\text {st }}$ Feb. at dormant bud stage.

- (T3) Spraying by Hydrogen cyanamide $1.5 \%$ on $1^{\text {st }}$ Jan., $15^{\text {th }}$ Jan. and the $1^{\text {st }}$ Feb. at dormant bud stage.

- (T4) Spraying by Hydrogen cyanamide $3 \%$ on $1^{\text {st }}$ Jan., $15^{\text {th }}$ Jan. and the $1^{\text {st }}$ Feb. at dormant bud stage.

- (T5) Spraying by Hydrogen cyanamide $4.5 \%$ on $1^{\text {st }}$ Jan., $15^{\text {th }} \mathrm{Jan}$. and the $1^{\text {st }} \mathrm{Feb}$. at dormant bud stage.

Table (1): Meteorological data (maximum and minimum temperature and relative humidity) for 2014 and 2015 under Assuit climatic conditions.

\begin{tabular}{|c|c|c|c|c|c|c|c|c|c|c|c|c|}
\hline \multirow{2}{*}{ Month } & \multicolumn{9}{|c|}{ Temperature $\left({ }^{\mathbf{O}} \mathbf{C}\right)$} & \multicolumn{5}{c|}{ Humidity (\%) } \\
\cline { 2 - 14 } & $\mathbf{2 0 1 4}$ & \multicolumn{2}{|c|}{$\mathbf{2 0 1 5}$} & \multicolumn{2}{|c|}{$\mathbf{2 0 1 6}$} & \multicolumn{2}{|c|}{$\mathbf{2 0 1 4}$} & \multicolumn{2}{|c|}{$\mathbf{2 0 1 5}$} & \multicolumn{2}{c|}{$\mathbf{2 0 1 6}$} \\
\cline { 2 - 13 } & Min. & Max. & Min. & Max. & Min. & Max. & Min. & Max. & Min. & Max. & Min. & Max. \\
\hline Oct. & 16.77 & 30.97 & 19.36 & 32.68 & 17.61 & 32.52 & 18.29 & 56.59 & 24.55 & 75.87 & 20.93 & 81.52 \\
\hline Nov. & 12.00 & 26.3 & 12.67 & 25.18 & 12.63 & 26.67 & 25.13 & 70.23 & 31.48 & 84.17 & 24.4 & 83.37 \\
\hline Dec. & 8.26 & 22.68 & 7.06 & 20.19 & 8.26 & 22.68 & 27.42 & 70.97 & 32.13 & 88.55 & 27.42 & 70.97 \\
\hline Jan. & 6.13 & 22.36 & 5.23 & 20.23 & 6.13 & 22.36 & 27.29 & 83.45 & 23.94 & 67.77 & 27.29 & 83.45 \\
\hline Feb. & 7.25 & 23.57 & 7.43 & 22.44 & 7.25 & 23.57 & 19.57 & 77.82 & 19.39 & 62.21 & 19.57 & 77.82 \\
\hline Mar. & 12.03 & 27.48 & 11.71 & 26.9 & 12.03 & 27.48 & 15.87 & 68.84 & 15.87 & 58.94 & 15.89 & 68.48 \\
\hline April & 15.63 & 32.37 & 14.17 & 29.30 & 17.07 & 34.73 & 12.27 & 61.73 & 10.67 & 42.53 & 9.23 & 60.97 \\
\hline May & 19.48 & 35.32 & 19.61 & 35.32 & 19.93 & 35.9 & 13.74 & 59.6 & 12.74 & 47.00 & 9.58 & 51.61 \\
\hline June & 21.03 & 36.27 & 21.13 & 36.40 & 24.43 & 40.4 & 17.76 & 52.83 & 16.1 & 61.70 & 9.60 & 50.63 \\
\hline July & 23.32 & 38.13 & 22.77 & 38.36 & 23.84 & 37.6 & 15.45 & 55.8 & 13.35 & 61.48 & 16.29 & 62.32 \\
\hline Aug. & 23.07 & 38.10 & 24.42 & 39.90 & 23.84 & 36.97 & 17.00 & 57.42 & 15.29 & 64.42 & 15.19 & 60.26 \\
\hline Sept. & 21.20 & 34.33 & 23.63 & 38.33 & 21.43 & 34.8 & 16.93 & 56.83 & 16.87 & 60.50 & 19.07 & 69.00 \\
\hline
\end{tabular}

*The meteorological data obtained by Meteorology Organization in Cairo. 
- (T6) Spraying by Mineral Oil 3\% + Hydrogen cyanamide $1.5 \%$ on $1^{\text {st }} \mathrm{Jan} ., 15^{\text {th }} \mathrm{Jan}$. and the $1^{\text {st }}$ of Feb. at dormant bud stage.

- (T7) Spraying by Mineral Oil 3\% + Hydrogen cyanamide $3 \%$ of $1^{\text {st }} \mathrm{Jan}$., $15^{\text {th }} \mathrm{Jan}$. and the $1^{\text {st }}$ Feb. at dormant bud stage.

- (T8) Spraying by Mineral Oil 3\% + Hydrogen cyanamide $4.5 \%$ on $1^{\text {st }} \mathrm{Jan} ., 15^{\text {th }} \mathrm{Jan}$. and the $1^{s t} \mathrm{Feb}$. at dormant bud stage.

\subsection{Experimental Design}

Selected pomegranate trees ( 66 bearing trees) of Manfalouty cv. were set as a randomized complete block design (RCBD) with 7 treatments, and 3 replicates (one tree per replicate), at 3 application time, in addition to 3 trees as a control. The treatments were arranged as main plot, whereas the application times laid out as sub plots.

\subsection{Variables measured}

\subsubsection{Sprouting percentage for bud break}

Sprouting percentage for bud break was recorded at each treatment. This stage was estimated by counted the total number of buds sprouted per shoot at the last week of February (beginning of flowering of the best treatment) and the total number of dormant buds per shoot. The percentage of sprouting was calculated as: Sprouting $(\%)=$

Total number of buds sprouted per shoot

Total number of dormant buds per shoot

\subsubsection{Vegetative growth parameters}

\subsubsection{Shoot length $(\mathrm{cm})$ and leaf number per shoot}

In each season, ten one-year-old shoots were tagged randomly at different sides of the tree canopy (replicate) to determine the shoot length and leaf number per shoot at the end of the growing season in July.

\subsubsection{Leaf area $\left(\mathrm{cm}^{2}\right)$}

Samples of approximately 30 mature leaves per treatment were taken from the mid shoot growth (one year-old) from the four sides of the tree to determine average leaf surface area $\left(\mathrm{cm}^{2}\right)$ according to the equation described by (Mofeed, 2009).

Leaf area $\left(\mathrm{cm}^{2}\right)=0.41$ (leaf length $\mathrm{x}$ leaf width) $+1.83$

\subsubsection{Blooming characteristics}

\subsection{Full bloom and blooming periods} (days)

Full bloom periods (days) were recorded at each treatment as the number of days from spraying to full bloom (at $75 \%$ anthesis), this stage was estimated by recording time of spraying and full blooming days, then days from spraying to full bloom date was calculated. Blooming periods (days) recorded for each treatment as the number of days from beginning of flowering to full bloom date. This stage was estimated by recorded time of beginning of flowering and full bloom in days, then days from beginning of flowering to full bloom date was calculated.

\subsection{Flowering percentage}

Flowering percentage was recorded for each treatment. This parameter was estimated by counting the total number of flowers per shoot at full bloom and the total number of bud burst per shoot. The percentage of flowering was calculated as:

Flowering $(\%)=$

Total number of flowers per shoot

Total number of buds sprouted per shoot $\times 100$

\subsection{Fruiting}

\subsubsection{Fruit set percentage}

Ten one-year-old shoots of each-tree (replicate) were selected and tagged at random. the total number of flowers per shoot was counted at full bloom and set fruits was counted two weeks after full bloom stage. The percentage of fruit set (FS \%) was calculated as: FS $\%=$

$\frac{\text { Number of fruitlets per shoot }}{\text { Total number of flowers per shoot at full bloom }} \times 100$

The number of dropped fruits were counted every 15 day intervals until harvesting and calculated as percentages (based on fruit set).

\subsubsection{Fruit maturity (days)}

Fruit maturity (days) was recorded for each treatment. This stage was obtained when the fruits reached the marketable maturity stage (total soluble solids, TSS) reached $14 \%$ of the best treatment). In each season, the time of full bloom and harvesting date were recorded in days for each treatment, then days from full bloom to harvesting date were calculated.

\subsubsection{Fruit number per tree}

In each season, the number of fruits per tree was recorded for each treatment at harvest time.

\subsubsection{Fruit yield (Kg/tree)}

At harvest time when the fruits reached the marketable maturity stage, fruits were picked of all treated trees on August $9^{\text {th }}$ and $5^{\text {th }}$ in the first and the second season, respectively, fruits were counted and weighed to estimate the number of fruits and yield/tree $(\mathrm{kg})$. 


\subsubsection{Cracking fruit, sun burn fruit and marketable fruit percentage}

In each season, at harvest time the number of cracked fruit, sun burned fruits and marketable fruits per tree were recorded. The percentages were calculated as:

Cracking fruit $\%=$ Number of cracking fruit per tree

Total number of fruits per tree

Sun burn fruits $\%=$

Number of sun burn fruit per tree

Total number of fruits per tree $\times 100$

Marketable fruit $\%=$

Number of marketable fruit per tree

Total number of fruits per tree

\subsection{Fruit quality}

After fruit harvest, five fruits from each replicate were randomly selected and directly taken to the laboratory of Fruit research of Horticulture Department, Faculty of Agriculture, Sohag University, to evaluate the following fruit physical and chemical characteristics.

\subsubsection{Fruit physical characteristics}

These included fruit weight $(\mathrm{g})$, fruit peel weight $(\mathrm{g})$, fruit grains weight $(\mathrm{g})$, fruit length and diameter $(\mathrm{cm})$, fruit volume $\left(\mathrm{cm}^{3}\right)$, fruit juice $(\mathrm{ml})$ were estimated using conventional methods, and the fruit shape index was calculated.

\subsubsection{Fruit weight (g)}

It was determined by weighting the fresh fruit samples (5 fruits) and the average fruit weight was recorded in (g.).

\subsubsection{Fruit peel weight, fruit grain weight (g) and fruit juice $(\mathrm{ml})$}

Selected fruits were peeled by hand in the laboratory, then, the average fruit peel weight (g) and fruit grains weight $(\mathrm{g})$ were recorded, as well as fruit juice $(\mathrm{ml})$.

\subsubsection{Fruit chemical content}

\subsubsection{Total anthothyanin percentage in rind} and aril

Total anthocyanin (\%) content in fruit juice and rind were measured as described by (Hsia et. al., 1965).

2.6.3.2. Total tannins content percentage in rind and aril.

Tannins content was determined in fruit juice aril and rind by the method described by (Winton and Winton, 1945)

2.6.3.3.Total soluble solids(TSS) and acidity (\%)

Total soluble solids (TSS \%) was measured by a hand refractmeter. Total acidity was determined by titration with $\mathrm{NaOH}$ at $0.1 \mathrm{~N}$ and phenolphthalein as an indicator, and then expressed as gm citric acid/ $100 \mathrm{ml}$ juice, according to A.O.A.C. (1985).

\subsubsection{Total soluble solids (TSS)/acid ratio}

TSS/acid ratio was estimated mathematically by dividing the value of TSS with titrable acidity.

\subsubsection{Vitamin $\mathrm{C}$ (mg/100 $\mathrm{ml}$ juice)}

Vitamin-C content (mg) Ascorbic acid/100 $\mathrm{ml}$ juice was determined according to the method given in A.O.A.C. (2000).

\subsection{Statistical analysis}

All data collected were subjected to statistical analysis of variance (ANOVA) and significant difference among means were determined according to (Snedecor and Cochran, 1972). In addition significant difference among means were distinguished according to the Duncan's, multiple test range (Duncan, 1955) whereas, capital and small letters were used for differentiating the values of specific and interaction effects of investigated factors, respectively.

\section{RESULTS AND DISCUSSION}

The highest significant values of vegetative bud burst were achieved by $1^{\text {st }}$ January x MO $3 \%+$ H.C. $4.5 \%$ (86.43 and 95.33) in both seasons compared with the control and other treatments. The present results are in harmony with those obtained by Gehan et al. (2011) and Sabry et al. (2011) who pointed out that Hydrogen cyanamide in association with mineral oil advanced the date of bud break (Table 2).

As for the flowering period (days) data showed that the least period was achieved at the $1^{s t}$ February x MO 3\% + H.C. 1.5\% (24.00) in the first season and the control (26.00) in the second season compared to the other treatments. Elloumi et al. (2013) and Seif El-Yazal et al. (2014) revealed that hydrogen cyanamide advanced flowering period in comparison to the untreated control (Table 3).

Data presented in Table (4) illustrate significantly that fruit set percentage was the highest achieved by the interaction treatment at $1^{\text {st }}$ January x MO 3\% + H.C. 3\% (37.78) and $1^{\text {st }}$ Feb. x H.C. $4.5 \%$ (37.78) in the first season compared with the control and other treatments. Seif ElYazal et al. (2014) noticed the efficiency of early bud break induced by Hydrogen cyanamide, and mineral oil in varying degrees. Although Hydrogen cyanamide was distinguished, all dormancybreaking substances improved fruit-set $\%$ as compared to the control. 
Table (2): Mean values of Hydrogen cyanamide and mineral oil application alone or in combination with different concentrations and dates on the percentage of vegetative bud burst of Manfalouty pomegranate during 2014 and 2015 seasons.

\begin{tabular}{|c|c|c|c|c|c|c|c|c|}
\hline \multirow{2}{*}{$\begin{array}{l}\text { Spraying dates } \\
\text { Treatments }\end{array}$} & \multicolumn{3}{|c|}{2014} & \multirow{2}{*}{ Mean } & \multicolumn{3}{|c|}{2015} & \multirow{2}{*}{ Mean } \\
\hline & $\mathbf{1}^{\text {st }}$ Jan. & $15^{\text {th }}$ Jan. & $1^{s t}$ Feb. & & $1^{\text {st }}$ Jan. & $15^{\text {th }}$ Jan. & $1^{s t}$ Feb. & \\
\hline Control & 68.10f-h & 68.10f-h & 68.10f-h & $68.10 \mathrm{E}$ & $75.33 \mathrm{de}$ & $75.33 \mathrm{de}$ & $75.33 \mathrm{de}$ & $75.33 \mathrm{C}$ \\
\hline M.O 3\% & $64.83 \mathrm{~h}$ & $70.20 \mathrm{e}-\mathrm{h}$ & $70.33 \mathrm{e}-\mathrm{h}$ & $68.46 \mathrm{E}$ & $75.40 \mathrm{de}$ & $75.60 \mathrm{c}-\mathrm{e}$ & $78.70 \mathrm{~b}-\mathrm{e}$ & $76.57 \mathrm{BC}$ \\
\hline H.C. $1.5 \%$ & $65.90 \mathrm{gh}$ & $65.83 \mathrm{gh}$ & $81.10 b-d$ & $70.94 \mathrm{DE}$ & $75.87 \mathrm{c}-\mathrm{e}$ & $76.50 c-e$ & $75.60 \mathrm{c}-\mathrm{e}$ & $75.99 \mathrm{BC}$ \\
\hline H.C. $3 \%$ & 71.73de-h & $77.50 \mathrm{~b}-\mathrm{f}$ & $77.33 b-f$ & $75.52 \mathrm{CD}$ & $75.70 \mathrm{c}-\mathrm{e}$ & $78.90 \mathrm{~b}-\mathrm{e}$ & $82.10 b-d$ & $78.90 \mathrm{BC}$ \\
\hline H.C. $4.5 \%$ & $82.07 \mathrm{~b}-\mathrm{d}$ & $79.23 \mathrm{~b}-\mathrm{e}$ & $78.57 \mathrm{~b}-\mathrm{f}$ & $79.96 \mathrm{DC}$ & $79.20 \mathrm{~b}-\mathrm{e}$ & $72.93 \mathrm{e}$ & $78.87 \mathrm{~b}-\mathrm{e}$ & $77.00 \mathrm{BC}$ \\
\hline MO 3\% + H.C. $1.5 \%$ & $75.57 \mathrm{c}-\mathrm{g}$ & $82.70 \mathrm{bc}$ & $77.00 \mathrm{~b}-\mathrm{f}$ & $78.42 \mathrm{BC}$ & $78.17 \mathrm{~b}-\mathrm{e}$ & $82.60 \mathrm{~b}-\mathrm{d}$ & $84.00 \mathrm{bc}$ & $81.59 \mathrm{~A}-\mathrm{C}$ \\
\hline MO 3\% + H.C. 3\% & $83.57 b c$ & $81.20 \mathrm{~b}-\mathrm{d}$ & $85.13 b c$ & $83.30 \mathrm{AB}$ & $81.90 \mathrm{~b}-\mathrm{d}$ & $85.00 \mathrm{~b}$ & $81.43 \mathrm{~b}-\mathrm{e}$ & $82.78 \mathrm{AB}$ \\
\hline MO 3\% + V 4.5\% & $86.43 a$ & $86.57 \mathrm{~b}$ & $83.30 \mathrm{bc}$ & $88.77 \mathrm{~A}$ & $95.33 \mathrm{a}$ & $85.43 b$ & $83.37 \mathrm{~b}-\mathrm{d}$ & $88.04 \mathrm{~A}$ \\
\hline Mean & $76.03 \mathrm{~A}$ & $76.42 \mathrm{~A}$ & $77.61 \mathrm{~A}$ & & $79.61 \mathrm{~A}$ & $79.04 \mathrm{~A}$ & $79.93 \mathrm{~A}$ & \\
\hline
\end{tabular}

- MO = mineral oil. - H.C. = Hydrogen cyanamide

Mean separation within treatments, dates of spraying of the pomegranate trees and for their interaction according to L.S.D. at 0.05 level.

Table (3): Mean values of Hydrogen cyanamide and mineral oil application alone or in combination with different concentrations and dates on the flowering period (days) of Manfalouty pomegranate during 2014 and 2015 seasons.

\begin{tabular}{|l|c|c|c|c|c|c|c|c|}
\hline \multirow{2}{*}{ Treatments } & \multicolumn{9}{|c|}{$\mathbf{2 0 1 4}$} & \multicolumn{4}{c|}{$\mathbf{2 0 1 5}$} \\
\hline Control & $\mathbf{1}^{\text {st }}$ Jan. & $\mathbf{1 5}^{\text {th }}$ Jan. & $\mathbf{1}^{\text {st }}$ Feb. & Mean & $\mathbf{1}^{\text {st }}$ Jan. & $\mathbf{1 5}^{\text {th }}$ Jan. & $\mathbf{1}^{\text {st }}$ Feb. & Mean \\
\hline M.O 3\% & $33.00 \mathrm{a}-\mathrm{c}$ & $33.00 \mathrm{a}-\mathrm{c}$ & $33.00 \mathrm{a}-\mathrm{c}$ & $33.00 \mathrm{AB}$ & $26.00 \mathrm{e}$ & $26.00 \mathrm{e}$ & $26.00 \mathrm{e}$ & $26.00 \mathrm{D}$ \\
\hline H.C. 1.5\% & $36.00 \mathrm{ab}$ & $33.00 \mathrm{a}-\mathrm{c}$ & $36.00 \mathrm{a}$ & $35.00 \mathrm{~A}$ & $38.00 \mathrm{a}$ & $36.00 \mathrm{ab}$ & $33.00 \mathrm{a}-\mathrm{c}$ & $35.67 \mathrm{AB}$ \\
\hline H.C. 3\% & $32.00 \mathrm{a}-\mathrm{d}$ & $29.00 \mathrm{c}-\mathrm{g}$ & $30.00 \mathrm{c}-\mathrm{f}$ & $30.33 \mathrm{BC}$ & $32.00 \mathrm{~b}-\mathrm{d}$ & $38.00 \mathrm{a}$ & $38.00 \mathrm{a}$ & $36.00 \mathrm{~A}$ \\
\hline H.C. 4.5\% & $31.00 \mathrm{~b}-\mathrm{e}$ & $29.00 \mathrm{c}-\mathrm{g}$ & $36.00 \mathrm{a}$ & $32.00 \mathrm{AB}$ & $27.00 \mathrm{de}$ & $35.00 \mathrm{ab}$ & $35.00 \mathrm{ab}$ & $32.33 \mathrm{BC}$ \\
\hline MO 3\% + H.C. 1.5\% & $27.00 \mathrm{e}-\mathrm{f}$ & $29.00 \mathrm{c}-\mathrm{g}$ & $28.00 \mathrm{~d}-\mathrm{h}$ & $28.00 \mathrm{CD}$ & $28.00 \mathrm{c}-\mathrm{e}$ & $31.00 \mathrm{~b}-\mathrm{e}$ & $36.00 \mathrm{ab}$ & $31.66 \mathrm{C}$ \\
\hline MO 3\% + H.C. 3\% & $32.00 \mathrm{a}-\mathrm{d}$ & $26.00 \mathrm{f}-\mathrm{h}$ & $24.00 \mathrm{~h}$ & $27.33 \mathrm{CD}$ & $32.00 \mathrm{~b}-\mathrm{d}$ & $31.00 \mathrm{~b}-\mathrm{e}$ & $35.00 \mathrm{ab}$ & $32.67 \mathrm{~A}-\mathrm{C}$ \\
\hline MO 3\% + V 4.5\% & $27.00 \mathrm{e}-\mathrm{h}$ & $27.00 \mathrm{e}-\mathrm{h}$ & $28.00 \mathrm{CD}$ & $31.00 \mathrm{~b}-\mathrm{e}$ & $31.00 \mathrm{~b}-\mathrm{e}$ & $34.00 \mathrm{a}-\mathrm{d}$ & $32.00 \mathrm{C}$ \\
\hline Mean & $26.00 \mathrm{f}-\mathrm{h}$ & $29.00 \mathrm{c}-\mathrm{g}$ & $25.00 \mathrm{gh}$ & $26.67 \mathrm{D}$ & $31.00 \mathrm{~b}-\mathrm{e}$ & $29.00 \mathrm{c}-\mathrm{e}$ & $36.00 \mathrm{ab}$ & $26.67 \mathrm{D}$ \\
\hline
\end{tabular}

- MO = mineral oil. - H.C. = Hydrogen cyanamide

Mean separation within treatments, dates of spraying of the pomegranate trees and for their interaction according to L.S.D. at 0.05 level.

Table (4): Mean values of Hydrogen cyanamide and mineral oil application alone or in combination with different concentrations and dates on fruit set percentage of Manfalouty pomegranate during 2014 and 2015 seasons.

\begin{tabular}{|l|c|c|c|c|c|c|c|c|}
\hline \multirow{2}{*}{ Spraying dates } & \multicolumn{4}{c|}{$\mathbf{2 0 1 4}$} & \multicolumn{4}{c|}{ 2015 } \\
\cline { 2 - 9 } Treatments & $\mathbf{1}^{\text {st }}$ Jan. & $\mathbf{1 5}^{\text {th }}$ Jan. & $\mathbf{1}^{\text {st }}$ Feb. & Mean & $\mathbf{1}^{\text {st }}$ Jan. & 15 $^{\text {th }}$ Jan. & $\mathbf{1}^{\text {st }}$ Feb. & Mean \\
\hline Control & $32.78 \mathrm{a}-\mathrm{c}$ & $32.78 \mathrm{a}-\mathrm{c}$ & $32.78 \mathrm{a}-\mathrm{c}$ & $32.78 \mathrm{~A}$ & $33.13 \mathrm{a}$ & $33.13 \mathrm{a}$ & $33.13 \mathrm{a}$ & $33.13 \mathrm{~A}$ \\
\hline M.O 3\% & $35.55 \mathrm{a}-\mathrm{c}$ & $28.89 \mathrm{a}-\mathrm{c}$ & $27.78 \mathrm{a}-\mathrm{c}$ & $30.74 \mathrm{~A}$ & $33.97 \mathrm{a}$ & $33.97 \mathrm{a}$ & $27.78 \mathrm{a}$ & $32.90 \mathrm{~A}$ \\
\hline H.C. 1.5\% & $31.11 \mathrm{a}-\mathrm{c}$ & $26.11 \mathrm{ab}$ & $30.00 \mathrm{a}-\mathrm{c}$ & $29.07 \mathrm{~A}$ & $35.55 \mathrm{a}$ & $35.55 \mathrm{a}$ & $26.43 \mathrm{a}$ & $31.59 \mathrm{~A}$ \\
\hline H.C. 3\% & $32.78 \mathrm{a}-\mathrm{c}$ & $32.78 \mathrm{a}-\mathrm{c}$ & $25.00 \mathrm{c}$ & $30.18 \mathrm{~A}$ & $30.55 \mathrm{a}$ & $30.55 \mathrm{a}$ & $35.00 \mathrm{a}$ & $34.44 \mathrm{~A}$ \\
\hline H.C. 4.5\% & $33.97 \mathrm{a}-\mathrm{c}$ & $32.78 \mathrm{~b}-\mathrm{c}$ & $37.78 \mathrm{a}$ & $34.84 \mathrm{~A}$ & $26.19 \mathrm{a}$ & $26.19 \mathrm{a}$ & $31.11 \mathrm{a}$ & $30.03 \mathrm{~A}$ \\
\hline MO 3\% + H.C. 1.5\% & $28.97 \mathrm{a}-\mathrm{c}$ & $30.55 \mathrm{~b}-\mathrm{c}$ & $30.55 \mathrm{a}-\mathrm{c}$ & $30.02 \mathrm{~A}$ & $28.97 \mathrm{a}$ & $28.97 \mathrm{a}$ & $32.78 \mathrm{a}$ & $30.24 \mathrm{~A}$ \\
\hline MO 3\%+ H.C. 3\% & $37.78 \mathrm{a}$ & $35.55 \mathrm{a}-\mathrm{c}$ & $32.78 \mathrm{a}-\mathrm{c}$ & $35.37 \mathrm{~A}$ & $28.97 \mathrm{a}$ & $28.97 \mathrm{a}$ & $28.33 \mathrm{a}$ & $30.42 \mathrm{~A}$ \\
\hline MO 3\%+V 4.5\% & $36.94 \mathrm{a}-\mathrm{c}$ & $28.89 \mathrm{a}-\mathrm{c}$ & $35.00 \mathrm{a}-\mathrm{c}$ & $33.61 \mathrm{~A}$ & $30.16 \mathrm{a}$ & $30.16 \mathrm{a}$ & $31.11 \mathrm{a}$ & $31.00 \mathrm{~A}$ \\
\hline Mean & $33.73 \mathrm{~A}$ & $31.04 \mathrm{~A}$ & $31.46 \mathrm{~A}$ & - & $30.94 \mathrm{~A}$ & $30.94 \mathrm{~A}$ & $30.71 \mathrm{~A}$ & - \\
\hline
\end{tabular}

- MO = mineral oil. $\quad$ - H.C. $=$ Hydrogen cyanamide

Mean separation within treatments, dates of spraying of the pomegranate trees and for their interaction according to L.S.D. at 0.05 level.

Regarding fruit maturity (days), data showed that, there were significant differences between treatments in this respect. The least days in both seasons were recorded for MO 3\% + H.C. $4.5 \%$ (Table 5). Similar results were obtained by ElSharkawy and Osman (2009) and Hegazi (2012) 
as they found that Hydrogen cyanamide treatments advanced fruit maturity.

Regarding the effect on yield ( $\mathrm{kg} /$ tree) data in Table (6) revealed that, the highest significant values were achieved by the interaction treatment $\left(1^{s t}\right.$ January x MO $3 \%+$ H.C. $\left.4.5 \%\right)(33.27$ and 36.23) treatments in both seasons compared to the control and other treatments. Gehan et al. (2011) and Sabry et al. (2011) pointed out that Hydrogen cyanamide in association with mineral oil significantly improved fruit yield.

Data in Table (7) showed that the lowest cracking percentage was obtained by application of 1st January x MO 3\% + H.C. 4.5\% (4.34 and 4.67) in both growing seasons compared to the control and other treatments. Panwar et al. (1994) and Singh (1995) indicated that some of the major physiological disorders which adversely affect the production and quality of pomegranate are fruit cracking.

Percentage of sun bunted fruits was at significantly the lowest values achieved by $1^{\text {st }}$ January x MO 3\% + H.C. $4.5 \%$ (5.48 and 6.61) for both seasons, respectively. Panwar et al. (1994) and Singh (1995) found that some of the major physiological disorders which adversely affect the production and quality of pomegranate are internal breakdown and sun- scorching .

Results in Table (9) illustrated the effects on the fruits weight $(\mathrm{g})$. The results showed that the highest values were obtained at $1^{\text {st }}$ January x MO $3 \%+$ H.C. $4.5 \%$ (486.07 gm) in the first season and at $1^{s t}$ February x Hydrogen cyanamide $4.5 \%$ (442.00 gm) in the second season compared to other treatments. The present results coincided with those obtained by Gehan et al. (2011) and Sabry et al. (2011). They found that, the combination treatment of Jasmine oil + Hydrogen cyanamide resulted in high fruit quality.

The data presented in Table (10) indicated that, the using of MO $3 \%+$ H.C. $4.5 \%$ on $1^{\text {st }}$ January and MO $3 \%+$ H.C. $1.5 \%$ on $1^{\text {st }}$ January induced significantly the highest fruit grains weight $(\mathrm{g})$ in both growing seasons, compared to other treatments. These findings are in harmony with those obtained by Gehan et al. (2011) and Sabry et al. (2011). who showed that, the combination treatment of Jasmine oil + Hydrogen cyanamide resulted in high fruit quality.

The fruit juice $(\mathrm{ml})$, was significantly the highest by ${ }^{s t}$ January x MO $3 \%+$ H.C. $4.5 \%$ and $1^{\text {st }}$ January x MO 3\% + H.C. $1.5 \%$ (191.00 and 170.93) in both growing seasons, compared to other treatments (Table 11). The results are in line with those obtained by Gehan et al. (2011) and
Sabry et al. (2011) who showed that, the combination treatment of Jasmine oil + Hydrogen cyanamide resulted in high fruit quality (Table 11).

Regarding the total anthothianin percentage in aril, the results indicated that the highest significant values were achieved by $1^{\text {st }}$ January $\mathrm{x}$ MO 3\% + H.C. $4.5 \%(0.46$ and $0.44 \%)$ in both seasons compared to the control and other treatments. The present results are in harmony with those obtained by Hegazi (2012) and Ahmed et al. (2014). Hydrogen cyanamide applied in January or February promotes fruit quality (Table 12).

As for total anthothianin percentage in the rind, the data in (Table 13) indicated that the highest significant values were achieved by $1^{\text {st }}$ January MO 3\% + H.C. $4.5 \%(0.28,0.26 \%)$ in both season respectively compared with the other treatments. The results are in harmony with those obtained by Gehan et al. (2011) and Sabry et al. (2011) who showed that, the combination treatment of Jasmine oil + Hydrogen cyanamide resulted in high fruit quality.

Data in Table (14) showed that the lowest significant total tannins in rind were obtained by $1^{\text {st }}$ January $\mathrm{x}$ MO $3 \%+$ H.C. $4.5 \%$ and $1^{\text {st }}$ January $x$ MO 3\% (2.67 and 1.70) in both growing seasons compared to the other treatments. The results are in line with those obtained by Gehan et al. (2011) and Sabry et al. (2011) who showed that, the combination treatment of Jasmine oil + Hydrogen cyanamide resulted in high fruit quality.

Data in Table (15) clearly indicated that the highest values of total soluble solids (TSS \%) percentage was achieved by $1^{\text {st }}$ January x MO $3 \%+$ H.C. $4.5 \%$ (15.07 and 15.00) in both growing seasons, respectively compared to the other treatments. The results are in harmony with those obtained by Gehan et al. (2011) and Sabry et al. (2011) who showed that, the combination treatment of Jasmine oil + Hydrogen cyanamide resulted in high fruit quality.

Data in Table (16) showed that the lowest significant acidity percentages, were obtained by $1^{\text {st }}$ January x MO $3 \%+$ H.C. $4.5 \%$ (1.16 and $1.26 \%$ ) in both seasons, respectively, compared to the other treatments. These results are in line with those gained by Gehan et al. (2011) and Sabry et al. (2011) which showed that, the combination treatment of Jasmine oil + Hydrogen cyanamide resulted in high fruit quality. 
Table (5): Mean values of Hydrogen cyanamide and Mineral Oil application alone or in combination with different concentrations and dates on fruit maturity (days) of Manfalouty pomegranate during 2014 and 2015 seasons.

\begin{tabular}{|c|c|c|c|c|c|c|c|c|}
\hline \multirow{2}{*}{ Spraying dates } & \multicolumn{4}{|c|}{2014} & \multicolumn{4}{|c|}{2015} \\
\hline & $1^{\text {st }}$ Jan. & $15^{\text {th }}$ Jan. & $1^{\text {st }}$ Feb. & Mean & $\mathbf{1}^{\text {st }} \mathrm{Jan}$. & $15^{\text {th }}$ Jan. & $1^{\text {st }}$ Feb. & Mean \\
\hline Control & 138.00hi & $147.00 \mathrm{~b}-\mathrm{d}$ & $153.00 \mathrm{a}$ & $146.00 \mathrm{AB}$ & $153.00 \mathrm{a}$ & $153.00 \mathrm{a}$ & $153.00 \mathrm{a}$ & $153.00 \mathrm{~A}$ \\
\hline M.O 3\% & $142.00 \mathrm{~d}-\mathrm{g}$ & $141.00 \mathrm{e}-\mathrm{h}$ & $151.00 \mathrm{ab}$ & $144.67 \mathrm{AB}$ & $137.00 \mathrm{e}-\mathrm{g}$ & $135.00 \mathrm{fg}$ & $146.00 \mathrm{~b}$ & $139.33 \mathrm{~B}$ \\
\hline H.C. $1.5 \%$ & $139.00 \mathrm{gh}$ & $146.00 \mathrm{c}-\mathrm{e}$ & $145.00 \mathrm{c}-\mathrm{f}$ & $143.33 \mathrm{~A}-\mathrm{C}$ & 142.00b-e & $139.00 \mathrm{~d}-\mathrm{f}$ & $135.00 \mathrm{fg}$ & $138.67 \mathrm{~B}$ \\
\hline H.C. 3\% & $139.00 f-h$ & $145.00 \mathrm{c}-\mathrm{e}$ & $140.00 f-h$ & $141.33 \mathrm{BC}$ & $136.00 \mathrm{fg}$ & $147.00 \mathrm{~b}$ & 144.00b-d & 142.33B \\
\hline H.C. $4.5 \%$ & $143.00 \mathrm{~d}-\mathrm{g}$ & $145.00 \mathrm{c}-\mathrm{f}$ & $149.00 \mathrm{a}-\mathrm{c}$ & $145.67 \mathrm{~A}$ & $146.00 \mathrm{~b}$ & $145.00 \mathrm{bc}$ & $135.00 \mathrm{fg}$ & $142.00 \mathrm{~B}$ \\
\hline MO 3\% + H.C. $1.5 \%$ & $143.00 d-g$ & $143.00 d-g$ & $143.00 d-g$ & $143.00 \mathrm{~A}-\mathrm{C}$ & 142.00b-e & $140.00 c-f$ & $144.00 \mathrm{~b}-\mathrm{d}$ & $142.00 \mathrm{~B}$ \\
\hline MO 3\% + H.C. 3\% & $139.00 \mathrm{~g}-\mathrm{i}$ & $143.00 d-g$ & $145.00 \mathrm{c}-\mathrm{f}$ & $142.33 \mathrm{~A}-\mathrm{C}$ & $139.00 d-f$ & 143.00b-d & $139.00 d-f$ & 140.33B \\
\hline MO 3\% + V 4.5\% & $134.00 \mathrm{i}$ & $145.00 \mathrm{c}-\mathrm{f}$ & 140.00f-h & $139.67 \mathrm{C}$ & $133.00 \mathrm{~g}$ & $142.00 \mathrm{~b}-\mathrm{e}$ & $144.00 \mathrm{~b}-\mathrm{d}$ & 139.67B \\
\hline Mean & $139.63 \mathrm{~B}$ & $144.38 \mathrm{~A}$ & $145.75 \mathrm{~A}$ & & $141.00 \mathrm{~B}$ & $143.00 \mathrm{~A}$ & $142.50 \mathrm{AB}$ & \\
\hline
\end{tabular}

-MO = mineral oil.

- H.C. = Hydrogen cyanamide

Mean separation within treatments, dates of spraying of the pomegranate trees and for their interaction according to L.S.D. at 0.05 level.

Table (6): Mean values of Hydrogen cyanamide and mineral oil application alone or in combination with different concentrations and dates on fruit yield (Kg/tree) of Manfalouty pomegranate during 2014 and 2015 seasons.

\begin{tabular}{|c|c|c|c|c|c|c|c|c|}
\hline \multirow{2}{*}{ Spraying dates } & \multicolumn{4}{|c|}{2014} & \multicolumn{4}{|c|}{2015} \\
\hline & $\mathbf{1}^{\text {st }}$ Jan. & $15^{\text {th }}$ Jan. & $1^{\text {st }}$ Feb. & Mean & $\mathbf{1}^{\text {st }} \mathrm{Jan}$. & $15^{\text {th }}$ Jan. & $1^{s t}$ Feb. & Mean \\
\hline Control & $18.83 \mathrm{bc}$ & $18.83 \mathrm{bc}$ & $18.83 \mathrm{bc}$ & $18.83 \mathrm{~A}$ & $24.13 \mathrm{ab}$ & $24.13 \mathrm{ab}$ & $24.13 \mathrm{ab}$ & $24.13 \mathrm{~A}$ \\
\hline M.O 3\% & $25.77 a-c$ & $26.73 b c$ & $17.80 \mathrm{bc}$ & $23.43 \mathrm{~A}$ & $30.30 \mathrm{ab}$ & $31.27 \mathrm{ab}$ & $18.33 \mathrm{ab}$ & $26.63 \mathrm{~A}$ \\
\hline H.C. $1.5 \%$ & $24.50 \mathrm{a}-\mathrm{c}$ & $20.17 a-c$ & $21.60 \mathrm{a}-\mathrm{c}$ & $22.09 \mathrm{~A}$ & $31.10 \mathrm{ab}$ & $19.90 \mathrm{ab}$ & $23.33 \mathrm{ab}$ & $24.78 \mathrm{~A}$ \\
\hline H.C. 3\% & $21.27 \mathrm{a}-\mathrm{c}$ & $18.80 \mathrm{bc}$ & $16.30 \mathrm{c}$ & $18.79 \mathrm{~A}$ & $25.73 \mathrm{ab}$ & $22.47 \mathrm{ab}$ & $18.00 \mathrm{~b}$ & $22.07 \mathrm{~A}$ \\
\hline H.C. $4.5 \%$ & $19.53 b c$ & $19.80 \mathrm{bc}$ & $27.67 a-c$ & $22.33 \mathrm{~A}$ & $25.16 \mathrm{ab}$ & $18.63 \mathrm{ab}$ & $28.07 \mathrm{ab}$ & $23.95 \mathrm{~A}$ \\
\hline MO 3\% + H.C. $1.5 \%$ & $26.60 a-c$ & $26.80 \mathrm{a}-\mathrm{c}$ & $16.37 \mathrm{c}$ & $23.26 \mathrm{~A}$ & $31.23 \mathrm{ab}$ & $19.90 \mathrm{ab}$ & $18.70 \mathrm{ab}$ & $23.28 \mathrm{~A}$ \\
\hline MO 3\% + H.C. 3\% & $30.30 \mathrm{ab}$ & $24.47 a-c$ & $19.07 b c$ & $24.61 \mathrm{~A}$ & $27.97 \mathrm{ab}$ & $31.13 \mathrm{ab}$ & $18.87 \mathrm{ab}$ & $25.99 \mathrm{~A}$ \\
\hline MO 3\% + V 4.5\% & $33.27 \mathrm{a}$ & $30.83 \mathrm{ab}$ & $24.13 a-c$ & $29.41 \mathrm{~A}$ & $36.23 a$ & $32.60 \mathrm{ab}$ & $21.57 \mathrm{ab}$ & $30.13 \mathrm{~A}$ \\
\hline \begin{tabular}{|c|} 
Mean \\
\end{tabular} & $25.01 \mathrm{~A}$ & $23.30 \mathrm{AB}$ & $20.22 \mathrm{~B}$ & - & $28.98 \mathrm{~A}$ & $25.00 \mathrm{AB}$ & $21.38 \mathrm{~B}$ & - \\
\hline
\end{tabular}

- MO = mineral oil. - H.C. = Hydrogen cyanamide

Mean separation within treatments, dates of spraying of the pomegranate trees and for their interaction according to L.S.D. at 0.05 level.

Table (7): Mean values of Hydrogen cyanamide and mineral oil application alone or incombination with different concentrations and dates on fruit cracking percentage of Manfalouty pomegranate during 2014 and 2015 seasons.

\begin{tabular}{|l|c|c|c|c|c|c|c|c|}
\hline \multirow{2}{*}{ Spraying dates } & \multicolumn{4}{c|}{$\mathbf{2 0 1 4}$} & \multicolumn{4}{c|}{$\mathbf{2 0 1 5}$} \\
\cline { 2 - 9 } Treatments & $\mathbf{1}^{\text {st }}$ Jan. & $\mathbf{1 5}^{\text {th }}$ Jan. & $\mathbf{1}^{\text {st }}$ Feb. & Mean & $\mathbf{1}^{\text {st }}$ Jan. & $\mathbf{1 5}^{\text {th }}$ Jan. & $\mathbf{1}^{\text {st }}$ Feb. & Mean \\
\hline Control & $11.87 \mathrm{a}-\mathrm{d}$ & $11.87 \mathrm{a}-\mathrm{d}$ & $11.87 \mathrm{a}-\mathrm{d}$ & $11.87 \mathrm{~A}$ & $13.57 \mathrm{a}$ & $13.57 \mathrm{a}$ & $13.57 \mathrm{a}$ & $13.57 \mathrm{~A}$ \\
\hline M.O 3\% & $11.60 \mathrm{a}-\mathrm{d}$ & $11.93 \mathrm{a}-\mathrm{d}$ & $12.37 \mathrm{a}-\mathrm{c}$ & $11.97 \mathrm{~A}$ & $12.13 \mathrm{a}-\mathrm{c}$ & $13.67 \mathrm{a}$ & $13.43 \mathrm{ab}$ & $13.08 \mathrm{AB}$ \\
\hline H.C. 1.5\% & $11.63 \mathrm{a}-\mathrm{d}$ & $11.53 \mathrm{a}-\mathrm{d}$ & $12.80 \mathrm{ab}$ & $11.99 \mathrm{~A}$ & $12.83 \mathrm{a}-\mathrm{c}$ & $12.07 \mathrm{a}-\mathrm{c}$ & $12.73 \mathrm{a}-\mathrm{c}$ & $12.54 \mathrm{~A}-\mathrm{C}$ \\
\hline H.C. 3\% & $11.40 \mathrm{a}-\mathrm{d}$ & $11.47 \mathrm{a}-\mathrm{d}$ & $11.00 \mathrm{a}-\mathrm{e}$ & $11.29 \mathrm{AB}$ & $11.80 \mathrm{a}-\mathrm{d}$ & $12.53 \mathrm{a}-\mathrm{c}$ & $11.53 \mathrm{a}-\mathrm{d}$ & $11.96 \mathrm{~B}-\mathrm{D}$ \\
\hline H.C. 4.5\% & $8.20 \mathrm{ef}$ & $11.80 \mathrm{a}-\mathrm{d}$ & $11.53 \mathrm{a}-\mathrm{d}$ & $10.51 \mathrm{AB}$ & $9.50 \mathrm{ef}$ & $12.17 \mathrm{a}-\mathrm{c}$ & $12.40 \mathrm{a}-\mathrm{c}$ & $11.36 \mathrm{D}$ \\
\hline MO 3\% + H.C. 1.5\% & $9.83 \mathrm{~b}-\mathrm{f}$ & $10.83 \mathrm{a}-\mathrm{e}$ & $13.00 \mathrm{a}$ & $11.22 \mathrm{AB}$ & $11.23 \mathrm{~b}-\mathrm{e}$ & $12.00 \mathrm{a}-\mathrm{c}$ & $12.13 \mathrm{a}-\mathrm{c}$ & $11.79 \mathrm{CD}$ \\
\hline MO 3\% + H.C. 3\% & $8.93 \mathrm{~d}-\mathrm{f}$ & $9.37 \mathrm{c}-\mathrm{f}$ & $10.20 \mathrm{a}-\mathrm{e}$ & $9.50 \mathrm{~B}$ & $9.73 \mathrm{~d}-\mathrm{f}$ & $11.77 \mathrm{a}-\mathrm{d}$ & $11.10 \mathrm{c}-\mathrm{e}$ & $10.87 \mathrm{DE}$ \\
\hline MO 3\% + V 4.5\% & $4.34 \mathrm{f}$ & $10.90 \mathrm{a}-\mathrm{e}$ & $10.23 \mathrm{a}-\mathrm{e}$ & $8.49 \mathrm{~B}$ & $4.67 \mathrm{f}$ & $11.00 \mathrm{c}-\mathrm{e}$ & $11.23 \mathrm{~b}-\mathrm{e}$ & $8.97 \mathrm{E}$ \\
\hline Control & $9.73 \mathrm{AB}$ & $11.21 \mathrm{~B}$ & $11.63 \mathrm{~A}$ & - & $10.68 \mathrm{~B}$ & $12.35 \mathrm{~A}$ & $12.27 \mathrm{~A}$ & - \\
\hline
\end{tabular}

- MO = mineral oil. $\quad$ - H.C. = Hydrogen cyanamide

Mean separation within treatments, dates of spraying of the pomegranate trees and for their interaction according to L.S.D. at 0.05 level. 
Table (8): Mean values of Hydrogen cyanamide and mineral oil application alone or in combination with different concentrations and dates on fruit sun burn percentage of Manfalouty pomegranate during 2014 and 2015 seasons.

\begin{tabular}{|l|c|c|c|c|c|c|c|c|}
\hline \multirow{2}{*}{ Spraying dates } & \multicolumn{4}{|c|}{$\mathbf{2 0 1 4}$} & \multicolumn{4}{c|}{$\mathbf{2 0 1 5}$} \\
\cline { 2 - 9 } Treatments & $\mathbf{1}^{\text {st }}$ Jan. & $\mathbf{1 5}^{\text {th }}$ Jan. & $\mathbf{1}^{\text {st }}$ Feb. & Mean & $\mathbf{1}^{\text {st }}$ Jan. & $\mathbf{1 5}^{\text {th }}$ Jan. & $\mathbf{1}^{\text {st }}$ Feb. & Mean \\
\hline Control & $21.60 \mathrm{a}$ & $21.60 \mathrm{a}$ & $21.60 \mathrm{a}$ & $21.60 \mathrm{~A}$ & $21.50 \mathrm{a}$ & $21.50 \mathrm{a}$ & $21.50 \mathrm{a}$ & $21.50 \mathrm{~A}$ \\
\hline M.O 3\% & $17.63 \mathrm{bc}$ & $18.23 \mathrm{a}-\mathrm{c}$ & $18.10 \mathrm{a}-\mathrm{c}$ & $17.99 \mathrm{~B}$ & $18.50 \mathrm{a}-\mathrm{e}$ & $19.80 \mathrm{a}-\mathrm{c}$ & $21.30 \mathrm{ab}$ & $19.87 \mathrm{~B}$ \\
\hline H.C. 1.5\% & $17.20 \mathrm{~b}-\mathrm{d}$ & $17.53 \mathrm{~b}-\mathrm{d}$ & $17.47 \mathrm{~b}-\mathrm{d}$ & $17.40 \mathrm{~B}$ & $19.73 \mathrm{a}-\mathrm{c}$ & $18.93 \mathrm{a}-\mathrm{d}$ & $19.60 \mathrm{a}-\mathrm{c}$ & $19.42 \mathrm{~B}$ \\
\hline H.C. 3\% & $16.60 \mathrm{~cd}$ & $20.70 \mathrm{ab}$ & $16.73 \mathrm{~cd}$ & $18.01 \mathrm{~B}$ & $16.80 \mathrm{c}-\mathrm{f}$ & $17.13 \mathrm{c}-\mathrm{f}$ & $18.10 \mathrm{a}-\mathrm{e}$ & $17.34 \mathrm{C}$ \\
\hline H.C. 4.5\% & $15.47 \mathrm{c}-\mathrm{e}$ & $16.57 \mathrm{~cd}$ & $16.13 \mathrm{c}-\mathrm{e}$ & $16.06 \mathrm{~B}$ & $14.23 \mathrm{fg}$ & $17.83 \mathrm{~b}-\mathrm{e}$ & $19.37 \mathrm{a}-\mathrm{c}$ & $17.14 \mathrm{C}$ \\
\hline MO 3\% + H.C. 1.5\% & $15.80 \mathrm{c}-\mathrm{e}$ & $16.23 \mathrm{c}-\mathrm{e}$ & $17.30 \mathrm{~b}-\mathrm{d}$ & $16.44 \mathrm{~B}$ & $15.63 \mathrm{~d}-\mathrm{g}$ & $17.10 \mathrm{c}-\mathrm{f}$ & $18.90 \mathrm{a}-\mathrm{d}$ & $17.21 \mathrm{C}$ \\
\hline MO 3\%+ H.C. 3\% & $12.67 \mathrm{ef}$ & $16.50 \mathrm{~cd}$ & $16.20 \mathrm{c}-\mathrm{e}$ & $15.12 \mathrm{BC}$ & $15.00 \mathrm{e}-\mathrm{g}$ & $17.07 \mathrm{c}-\mathrm{f}$ & $18.70 \mathrm{a}-\mathrm{d}$ & $16.92 \mathrm{CD}$ \\
\hline MO 3\% + V 4.5\% & $5.48 \mathrm{f}$ & $13.73 \mathrm{de}$ & $14.40 \mathrm{c}-\mathrm{e}$ & $11.20 \mathrm{C}$ & $6.61 \mathrm{~g}$ & $16.50 \mathrm{c}-\mathrm{f}$ & $17.13 \mathrm{c}-\mathrm{f}$ & $13.41 \mathrm{D}$ \\
\hline Control & $15.31 \mathrm{~B}$ & $17.64 \mathrm{~A}$ & $17.24 \mathrm{~A}$ & - & $16.81 \mathrm{C}$ & $18.23 \mathrm{~B}$ & $19.33 \mathrm{~A}$ & - \\
\hline
\end{tabular}

- MO = mineral oil.

- H.C. = Hydrogen cyanamide

Mean separation within treatments, dates of spraying of the pomegranate trees and for their interaction according to L.S.D. at 0.05 level.

Table (9): Mean values of Hydrogen cyanamide and mineral oil application alone or in combination with different concentrations and dates on fruits weight (g) of Manfalouty pomegranate during 2014 and 2015 seasons.

\begin{tabular}{|c|c|c|c|c|c|c|c|c|}
\hline \multirow{2}{*}{ Treatments } & \multicolumn{4}{|c|}{2014} & \multicolumn{4}{|c|}{2015} \\
\hline & $\mathbf{1}^{\text {st }} \mathrm{Jan}$. & $15^{\text {th }}$ Jan. & $\mathbf{1}^{\text {st }}$ Feb. & Mean & $\mathbf{1}^{\text {st }} \mathrm{Jan}$. & $15^{\text {st }}$ Jan. & $1^{\text {st }}$ Feb. & mean \\
\hline Control & $300.23 \mathrm{e}$ & $300.23 \mathrm{e}$ & $300.23 \mathrm{e}$ & $300.23 \mathrm{C}$ & $264.33 d$ & $264.33 d$ & $264.33 d$ & $264.33 \mathrm{D}$ \\
\hline M.O 3\% & $362.20 \mathrm{c}-\mathrm{e}$ & $385.07 b-e$ & 324.13 de & $357.13 \mathrm{BC}$ & $330.33 b-d$ & $363.33 a-d$ & $335.67 b-d$ & $343.11 \mathrm{C}$ \\
\hline H.C. $1.5 \%$ & 372.00b-e & 366.93b-e & 333.30de & $357.41 \mathrm{BC}$ & 389.33a-c & $377.00 \mathrm{abc}$ & $358.00 \mathrm{a}-\mathrm{d}$ & 374.78A-C \\
\hline H.C. 3\% & $363.83 c-e$ & $344.57 \mathrm{de}$ & $336.33 \mathrm{de}$ & 348.24BC & $354.33 \mathrm{a}-\mathrm{d}$ & $368.00 \mathrm{a}-\mathrm{d}$ & $385.67 \mathrm{a}-\mathrm{c}$ & $369.33 \mathrm{~A}-\mathrm{C}$ \\
\hline H.C. $4.5 \%$ & $362.27 \mathrm{c}-\mathrm{e}$ & $382.43 b-e$ & $441.33 a-c$ & $395.34 \mathrm{~B}$ & $442.00 \mathrm{a}$ & $419.67 \mathrm{abc}$ & $391.00 \mathrm{a}-\mathrm{c}$ & $417.56 \mathrm{~A}$ \\
\hline MO 3\% + H.C. $1.5 \%$ & $398.07 b-d$ & $394.80 b-d$ & $348.67 \mathrm{de}$ & $380.51 \mathrm{~B}$ & $431.33 \mathrm{ab}$ & $323.00 \mathrm{~cd}$ & $343.00 a-d$ & $365.78 \mathrm{BC}$ \\
\hline MO 3\% + H.C. 3\% & $483.87 \mathrm{a}$ & $335.33 \mathrm{de}$ & $386.50 \mathrm{~b}-\mathrm{e}$ & $401.90 \mathrm{AB}$ & $356.67 a-d$ & $352.67 a-d$ & $410.67 a-c$ & 373.34A-C \\
\hline MO 3\% + V 4.5\% & $486.07 \mathrm{a}$ & $453.53 \mathrm{ab}$ & $454.07 \mathrm{ab}$ & $464.56 \mathrm{~A}$ & $422.00 \mathrm{a}-\mathrm{c}$ & $408.67 \mathrm{abc}$ & $382.33 \mathrm{a}-\mathrm{c}$ & $404.33 \mathrm{AB}$ \\
\hline Control & 391.07A & $370.36 \mathrm{~A}$ & $365.57 \mathrm{~A}$ & & $373.79 \mathrm{~A}$ & $359.58 \mathrm{~A}$ & $358.83 \mathrm{~A}$ & \\
\hline
\end{tabular}

- MO = mineral oil. - H.C. = Hydrogen cyanamide

Mean separation within treatments, dates of spraying of the pomegranate trees and for their interaction according to L.S.D. at 0.05 level.

Table (10): Mean values of Hydrogen cyanamide and mineral oil application alone or in combination with different concentrations and dates on fruit grains (g) of Manfalouty pomegranate during 2014 and 2015 seasons.

\begin{tabular}{|l|c|c|c|c|c|c|c|c|}
\hline \multirow{2}{*}{ Spraying dates } & \multicolumn{4}{|c|}{$\mathbf{2 0 1 4}$} & \multicolumn{4}{c|}{2015} \\
\cline { 2 - 9 } Treatments & $\mathbf{1}^{\text {st }}$ Jan. & $\mathbf{1 5}^{\text {th }}$ Jan. & $\mathbf{1}^{\text {st }}$ Feb. & Mean & $\mathbf{1}^{\text {st }}$ Jan. & $\mathbf{1 5}^{\text {th }}$ Jan. $^{\text {st }} \mathbf{1}^{\text {Feb. }}$ & Mean \\
\hline Control & $185.03 \mathrm{~g}$ & $185.03 \mathrm{~g}$ & $185.03 \mathrm{~g}$ & $185.03 \mathrm{D}$ & $140.00 \mathrm{c}$ & $140.00 \mathrm{c}$ & $140.00 \mathrm{c}$ & $140.00 \mathrm{~B}$ \\
\hline M.O 3\% & $178.87 \mathrm{~g}$ & $225.07 \mathrm{~b}-\mathrm{g}$ & $183.30 \mathrm{~g}$ & $195.75 \mathrm{CD}$ & $172.00 \mathrm{bc}$ & $186.33 \mathrm{bc}$ & $217.33 \mathrm{ab}$ & $191.89 \mathrm{~A}$ \\
\hline H.C. 1.5\% & $218.23 \mathrm{c}-\mathrm{g}$ & $185.40 \mathrm{~g}$ & $203.67 \mathrm{e}-\mathrm{g}$ & $202.43 \mathrm{CD}$ & $227.00 \mathrm{ab}$ & $186.33 \mathrm{bc}$ & $216.33 \mathrm{ab}$ & $226.55 \mathrm{~A}$ \\
\hline H.C. 3\% & $240.50 \mathrm{a}-\mathrm{f}$ & $195.57 \mathrm{fg}$ & $214.43 \mathrm{~d}-\mathrm{g}$ & $216.83 \mathrm{~B}-\mathrm{D}$ & $198.67 \mathrm{a}-\mathrm{c}$ & $195.33 \mathrm{a}-\mathrm{c}$ & $213.33 \mathrm{ab}$ & $202.44 \mathrm{~A}$ \\
\hline H.C. 4.5\% & $221.30 \mathrm{c}-\mathrm{g}$ & $254.33 \mathrm{a}-\mathrm{e}$ & $275.00 \mathrm{ab}$ & $250.21 \mathrm{AB}$ & $237.00 \mathrm{ab}$ & $229.00 \mathrm{ab}$ & $211.33 \mathrm{a}-\mathrm{c}$ & $225.78 \mathrm{~A}$ \\
\hline MO 3\%+ H.C. 1.5\% & $211.87 \mathrm{e}-\mathrm{g}$ & $228.70 \mathrm{~b}-\mathrm{g}$ & $217.13 \mathrm{c}-\mathrm{g}$ & $219.23 \mathrm{~B}-\mathrm{D}$ & $268.00 \mathrm{a}$ & $178.67 \mathrm{bc}$ & $193.00 \mathrm{bc}$ & $213.22 \mathrm{~A}$ \\
\hline MO 3\%+ H.C. 3\% & $266.03 \mathrm{a}-\mathrm{d}$ & $185.80 \mathrm{~g}$ & $251.77 \mathrm{a}-\mathrm{e}$ & $234.53 \mathrm{~A}-\mathrm{C}$ & $181.33 \mathrm{bc}$ & $205.00 \mathrm{a}-\mathrm{c}$ & $232.67 \mathrm{ab}$ & $206.33 \mathrm{~A}$ \\
\hline MO 3\%+ V 4.5\% & $289.17 \mathrm{a}$ & $266.97 \mathrm{a}-\mathrm{c}$ & $282.83 \mathrm{a}$ & $279.66 \mathrm{~A}$ & $204.00 \mathrm{a}-\mathrm{c}$ & $227.00 \mathrm{ab}$ & $217.67 \mathrm{ab}$ & $216.22 \mathrm{~A}$ \\
\hline Control & $226.38 \mathrm{~A}$ & $215.86 \mathrm{~A}$ & $226.65 \mathrm{~A}$ & - & $203.50 \mathrm{~A}$ & $199.71 \mathrm{~A}$ & $205.21 \mathrm{~A}$ & - \\
\hline
\end{tabular}

- MO = mineral oil.

- H.C. = Hydrogen cyanamide

Mean separation within treatments, dates of spraying of the pomegranate trees and for their interaction according to L.S.D. at 0.05 level. 
Table (11): Mean values of Hydrogen cyanamide and mineral oil application alone or in combination with different concentrations and dates on fruit juice $(\mathrm{ml})$ of Manfalouty pomegranate during 2014and 2015 seasons.

\begin{tabular}{|l|c|c|c|c|c|c|c|c|}
\hline \multirow{2}{*}{ Spraying dates } & \multicolumn{4}{|c|}{$\mathbf{2 0 1 4}$} & \multicolumn{3}{c|}{2015} \\
\cline { 2 - 9 } Treatments & $\mathbf{1}^{\text {st }}$ Jan. & $\mathbf{1 5}^{\text {th }}$ Jan. & $\mathbf{1}^{\text {st }}$ Feb. & Mean & $\mathbf{1}^{\text {st }}$ Jan. & $\mathbf{1 5}^{\text {th }}$ Jan. & $\mathbf{1}^{\text {st }}$ Feb. & Mean \\
\hline Control & $110.76 \mathrm{~h}$ & $110.76 \mathrm{~h}$ & $110.76 \mathrm{~h}$ & $110.76 \mathrm{D}$ & $78.09 \mathrm{c}$ & $78.09 \mathrm{c}$ & $78.09 \mathrm{c}$ & $78.09 \mathrm{~B}$ \\
\hline M.O 3\% & $116.91 \mathrm{gh}$ & $143.04 \mathrm{c}-\mathrm{h}$ & $114.33 \mathrm{gh}$ & $124.76 \mathrm{CD}$ & $107.35 \mathrm{bc}$ & $116.78 \mathrm{bc}$ & $139.31 \mathrm{ab}$ & $121.15 \mathrm{~A}$ \\
\hline H.C. 1.5\% & $142.82 \mathrm{c}-\mathrm{h}$ & $115.56 \mathrm{gh}$ & $127.99 \mathrm{e}-\mathrm{h}$ & $128.79 \mathrm{CD}$ & $142.67 \mathrm{ab}$ & $149.24 \mathrm{ab}$ & $130.80 \mathrm{ab}$ & $140.90 \mathrm{~A}$ \\
\hline H.C. 3\% & $159.02 \mathrm{a}-\mathrm{f}$ & $124.33 \mathrm{e}-\mathrm{h}$ & $140.06 \mathrm{c}-\mathrm{h}$ & $141.14 \mathrm{BC}$ & $125.07 \mathrm{a}-\mathrm{c}$ & $125.05 \mathrm{a}-\mathrm{c}$ & $139.49 \mathrm{ab}$ & $129.87 \mathrm{~A}$ \\
\hline H.C. 4.5\% & $145.53 \mathrm{~b}-\mathrm{h}$ & $158.27 \mathrm{a}-\mathrm{f}$ & $174.77 \mathrm{a}-\mathrm{d}$ & $159.52 \mathrm{AB}$ & $154.22 \mathrm{ab}$ & $146.56 \mathrm{ab}$ & $138.12 \mathrm{ab}$ & $146.30 \mathrm{~A}$ \\
\hline MO 3\% + H.C. 1.5\% & $137.87 \mathrm{~d}-\mathrm{h}$ & $150.79 \mathrm{~b}-\mathrm{g}$ & $151.92 \mathrm{~b}-\mathrm{g}$ & $146.86 \mathrm{BC}$ & $170.93 \mathrm{a}$ & $115.28 \mathrm{bc}$ & $124.07 \mathrm{a}-\mathrm{c}$ & $136.76 \mathrm{~A}$ \\
\hline MO 3\% + H.C. 3\% & $175.25 \mathrm{a}-\mathrm{d}$ & $119.99 \mathrm{f}-\mathrm{h}$ & $163.16 \mathrm{a}-\mathrm{e}$ & $152.80 \mathrm{BC}$ & $120.50 \mathrm{a}-\mathrm{c}$ & $133.31 \mathrm{ab}$ & $146.74 \mathrm{ab}$ & $133.52 \mathrm{~A}$ \\
\hline MO 3\% + V 4.5\% & $191.00 \mathrm{a}$ & $177.81 \mathrm{a}-\mathrm{c}$ & $183.73 \mathrm{ab}$ & $184.18 \mathrm{~A}$ & $134.07 \mathrm{~b}$ & $151.67 \mathrm{ab}$ & $143.66 \mathrm{ab}$ & $143.13 \mathrm{~A}$ \\
\hline Control & $147.40 \mathrm{~A}$ & $137.57 \mathrm{~A}$ & $145.84 \mathrm{~A}$ & - & $129.11 \mathrm{~A}$ & $127.00 \mathrm{~A}$ & $130.04 \mathrm{~A}$ & - \\
\hline
\end{tabular}

- $\mathrm{MO}=$ mineral oil.

- H.C. $=$ Hydrogen cyanamide

Mean separation within treatments, dates of spraying of the pomegranate trees and for their interaction according to L.S.D. at 0.05 level.

Table (12): Mean values of Hydrogen cyanamide and mineral oil application alone or in combination with different concentrations and dates on the total anthothianin percentage in aril of Manfalouty pomegranate during 2014 and 2015 seasons.

\begin{tabular}{|l|c|c|c|c|c|c|c|c|}
\hline \multirow{2}{*}{ Spraying dates } & \multicolumn{4}{c|}{$\mathbf{2 0 1 4}$} & \multicolumn{4}{c|}{$\mathbf{2 0 1 5}$} \\
\cline { 2 - 10 } Treatments & $\mathbf{1}^{\text {st }}$ Jan. & $\mathbf{1 5}^{\text {th }} \mathbf{J a n}$. & $\mathbf{1}^{\text {st }} \mathbf{F e b}$ & Mean & $\mathbf{1}^{\text {st }}$ Jan. & $\mathbf{1 5}^{\text {th }} \mathbf{J a n}$. & $\mathbf{1}^{\text {st }}$ Feb. & Mean \\
\hline Control & $0.21 \mathrm{e}$ & $0.21 \mathrm{e}$ & $0.21 \mathrm{e}$ & $0.21 \mathrm{D}$ & $0.22 \mathrm{~cd}$ & $0.22 \mathrm{~cd}$ & $0.22 \mathrm{~cd}$ & $0.22 \mathrm{~B}$ \\
\hline M.O 3\% & $0.26 \mathrm{de}$ & $0.30 \mathrm{~cd}$ & $0.26 \mathrm{de}$ & $0.27 \mathrm{BC}$ & $0.24 \mathrm{~cd}$ & $0.28 \mathrm{~cd}$ & $0.24 \mathrm{~cd}$ & $0.25 \mathrm{~B}$ \\
\hline H.C. 1.5\% & $0.24 \mathrm{de}$ & $0.27 \mathrm{de}$ & $0.24 \mathrm{de}$ & $0.25 \mathrm{CD}$ & $0.22 \mathrm{~cd}$ & $0.25 \mathrm{~cd}$ & $0.22 \mathrm{~cd}$ & $0.23 \mathrm{~B}$ \\
\hline H.C. 3\% & $0.25 \mathrm{de}$ & $0.30 \mathrm{c}-\mathrm{e}$ & $0.27 \mathrm{de}$ & $0.27 \mathrm{BC}$ & $0.23 \mathrm{~cd}$ & $0.28 \mathrm{~cd}$ & $0.25 \mathrm{~cd}$ & $0.25 \mathrm{~B}$ \\
\hline H.C. 4.5\% & $0.41 \mathrm{ab}$ & $0.25 \mathrm{de}$ & $0.32 \mathrm{~cd}$ & $0.33 \mathrm{~A}$ & $0.42 \mathrm{a}$ & $0.29 \mathrm{~cd}$ & $0.32 \mathrm{bc}$ & $0.34 \mathrm{~A}$ \\
\hline MO 3\% + H.C. 1.5\% & $0.37 \mathrm{bc}$ & $0.27 \mathrm{de}$ & $0.32 \mathrm{~cd}$ & $0.32 \mathrm{AB}$ & $0.27 \mathrm{~cd}$ & $0.24 \mathrm{~cd}$ & $0.30 \mathrm{~cd}$ & $0.27 \mathrm{~B}$ \\
\hline MO 3\% + H.C. 3\% & $0.43 \mathrm{ab}$ & $0.31 \mathrm{~cd}$ & $0.31 \mathrm{~cd}$ & $0.35 \mathrm{~A}$ & $0.41 \mathrm{ab}$ & $0.25 \mathrm{~cd}$ & $0.20 \mathrm{~d}$ & $0.29 \mathrm{AB}$ \\
\hline MO 3\% + V 4.5\% & $0.46 \mathrm{a}$ & $0.32 \mathrm{~cd}$ & $0.32 \mathrm{~cd}$ & $0.37 \mathrm{~A}$ & $0.44 \mathrm{a}$ & $0.32 \mathrm{bd}$ & $0.30 \mathrm{~cd}$ & $0.35 \mathrm{~A}$ \\
\hline Control & $0.33 \mathrm{~A}$ & $0.28 \mathrm{~B}$ & $0.28 \mathrm{~B}$ & - & $0.31 \mathrm{~A}$ & $0.27 \mathrm{~B}$ & $0.26 \mathrm{~B}$ & - \\
\hline
\end{tabular}

- $\mathrm{MO}=$ mineral oil. $\quad$ - H.C. $=$ Hydrogen cyanamide

Mean separation within treatments, dates of spraying of the pomegranate trees and for their interaction according to L.S.D. at 0.05 level.

Table (13): Mean values of Hydrogen cyanamide and mineral oil application alone or in combination with different concentrations and dates on the total anthothianin percentage in rind of Manfalouty pomegranate during 2014and 2015 seasons.

\begin{tabular}{|c|c|c|c|c|c|c|c|c|}
\hline \multirow{2}{*}{ Spraying dates } & \multicolumn{4}{|c|}{2014} & \multicolumn{4}{|c|}{2015} \\
\hline & $\mathbf{1}^{\text {st }} \mathrm{Jan}$. & $15^{\text {th }}$ Jan. & $\mathbf{1}^{s t}$ Feb. & Mean & $\mathbf{1}^{s t}$ Jan. & $15^{\text {th }}$ Jan. & $1^{s t}$ Feb. & Mean \\
\hline Control & $0.04^{\mathrm{h}}$ & $0.04^{\mathrm{h}}$ & $0.04^{\mathrm{h}}$ & $0.04^{\mathrm{C}}$ & $0.02^{1}$ & $0.02^{1}$ & $0.02^{1}$ & $0.02^{\mathrm{F}}$ \\
\hline M.O 3\% & $0.17^{\mathrm{b}}$ & $0.06^{\mathrm{gh}}$ & $0.13^{\text {bcde }}$ & $0.12^{\mathrm{B}}$ & $0.13^{\mathrm{e}}$ & $0.09^{\mathrm{g}}$ & $0.10^{\mathrm{f}}$ & $0.11^{\mathrm{C}}$ \\
\hline H.C. 1.5\% & $0.15^{\mathrm{bcd}}$ & $0.11^{\mathrm{c}-\mathrm{g}}$ & $0.12^{b-f}$ & $0.13^{\mathrm{B}}$ & $0.15^{\mathrm{d}}$ & $0.02^{1}$ & $0.11^{f}$ & $0.09^{\mathrm{CD}}$ \\
\hline H.C. 3\% & $0.11^{\mathrm{c}-\mathrm{g}}$ & $0.08^{\text {efgh }}$ & $0.10^{\mathrm{d}-\mathrm{h}}$ & $0.10^{\mathrm{B}}$ & $0.05^{j}$ & $0.04^{\mathrm{k}}$ & $0.08^{\mathrm{h}}$ & $0.06^{\mathrm{E}}$ \\
\hline H.C. $4.5 \%$ & $0.15^{\text {bcd }}$ & $0.15^{\text {bcd }}$ & $0.07^{\text {fgh }}$ & $0.12^{\mathrm{B}}$ & $0.09^{\mathrm{g}}$ & $0.02^{1}$ & $0.11^{\mathrm{f}}$ & $0.07^{\mathrm{DE}}$ \\
\hline MO 3\% + H.C. $1.5 \%$ & $0.14^{\text {bcde }}$ & $0.11^{\text {defg }}$ & $0.13^{b-f}$ & $0.13^{\mathrm{B}}$ & $0.13^{\mathrm{e}}$ & $0.13^{\mathrm{e}}$ & $0.05^{j}$ & $0.10^{\mathrm{CD}}$ \\
\hline MO 3\% + H.C. 3\% & $0.23^{\mathrm{a}}$ & $0.17^{\mathbf{b c}}$ & $0.14^{\text {bcd }}$ & $0.18^{\mathrm{A}}$ & $0.21^{\mathrm{b}}$ & $0.15^{\mathrm{d}}$ & $0.20^{\mathrm{c}}$ & $0.19^{\mathrm{A}}$ \\
\hline MO 3\% + V 4.5\% & $0.28^{\mathrm{a}}$ & $0.13^{\text {bcde }}$ & $0.10^{\text {d-h }}$ & $0.17^{\mathrm{A}}$ & $0.26^{\mathrm{a}}$ & $0.11^{\mathrm{f}}$ & $0.06^{i}$ & $0.14^{\mathrm{B}}$ \\
\hline Control & $0.16^{\mathrm{A}}$ & $0.11^{\mathrm{B}}$ & $0.10^{\mathrm{B}}$ & & $0.13^{\mathrm{A}}$ & $0.07^{\mathrm{C}}$ & $0.09^{\mathrm{B}}$ & \\
\hline
\end{tabular}

- MO = mineral oil.

- H.C. $=$ Hydrogen cyanamide

Mean separation within treatments, dates of spraying of the pomegranate trees and for their interaction according to L.S.D. at 0.05 level. 
Table (14): Mean values of Hydrogen cyanamide and mineral oil application alone or in combination with different concentrations and dates on the total tannins content percentage in rind of Manfalouty pomegranate during 2014and 2015 growing seasons.

\begin{tabular}{|l|c|c|c|c|c|c|c|c|}
\hline \multirow{2}{*}{$\begin{array}{c}\text { Spraying dates } \\
\text { Treatments }\end{array}$} & \multicolumn{4}{|c|}{$\mathbf{2 0 1 4}$} & \multicolumn{4}{c|}{$\mathbf{2 0 1 5}$} \\
\cline { 2 - 10 } & $\mathbf{1}^{\text {st }}$ Jan. & $\mathbf{1 5}^{\text {th }}$ Jan. & $\mathbf{1}^{\text {st }}$ Feb. & Mean & $\mathbf{1}^{\text {st }}$ Jan. & $\mathbf{1 5}^{\text {th }}$ Jan. & $\mathbf{1}^{\text {st }}$ Feb. & Mean \\
\hline Control & $3.53 \mathrm{a}$ & $3.53 \mathrm{a}$ & $3.53 \mathrm{a}$ & $3.53 \mathrm{~A}$ & $2.97 \mathrm{~b}-\mathrm{g}$ & $2.97 \mathrm{~b}-\mathrm{g}$ & $2.97 \mathrm{~b}-\mathrm{g}$ & $2.97 \mathrm{~B}$ \\
\hline M.O 3\% & $3.04 \mathrm{a}-\mathrm{c}$ & $3.28 \mathrm{ab}$ & $3.11 \mathrm{a}-\mathrm{c}$ & $3.14 \mathrm{~B}$ & $1.70 \mathrm{~h}$ & $3.09 \mathrm{a}-\mathrm{f}$ & $2.77 \mathrm{c}-\mathrm{g}$ & $2.52 \mathrm{~B}$ \\
\hline H.C. 1.5\% & $3.20 \mathrm{a}-\mathrm{c}$ & $3.12 \mathrm{a}-\mathrm{c}$ & $3.07 \mathrm{a}-\mathrm{c}$ & $3.13 \mathrm{~B}$ & $2.06 \mathrm{f}-\mathrm{h}$ & $3.25 \mathrm{a}-\mathrm{e}$ & $2.47 \mathrm{e}-\mathrm{h}$ & $2.59 \mathrm{~B}$ \\
\hline H.C. 3\% & $3.06 \mathrm{a}-\mathrm{c}$ & $3.32 \mathrm{ab}$ & $3.07 \mathrm{a}-\mathrm{c}$ & $3.15 \mathrm{~B}$ & $2.67 \mathrm{c}-\mathrm{h}$ & $3.73 \mathrm{a}-\mathrm{c}$ & $2.73 \mathrm{c}-\mathrm{h}$ & $3.04 \mathrm{~B}$ \\
\hline H.C. 4.5\% & $3.03 \mathrm{a}-\mathrm{c}$ & $3.12 \mathrm{a}-\mathrm{c}$ & $3.07 \mathrm{a}-\mathrm{c}$ & $3.07 \mathrm{~B}$ & $1.96 \mathrm{gh}$ & $3.19 \mathrm{a}-\mathrm{e}$ & $2.61 \mathrm{~d}-\mathrm{h}$ & $2.59 \mathrm{~B}$ \\
\hline MO 3\% + H.C. 1.5\% & $3.08 \mathrm{a}-\mathrm{c}$ & $3.23 \mathrm{ab}$ & $2.94 \mathrm{bc}$ & $3.08 \mathrm{~B}$ & $3.90 \mathrm{ab}$ & $4.06 \mathrm{a}$ & $3.66 \mathrm{a}-\mathrm{d}$ & $3.87 \mathrm{~A}$ \\
\hline MO 3\% + H.C. 3\% & $2.90 \mathrm{bc}$ & $3.07 \mathrm{a}-\mathrm{c}$ & $2.98 \mathrm{bc}$ & $2.98 \mathrm{~B}$ & $3.28 \mathrm{a}-\mathrm{e}$ & $3.04 \mathrm{a}-\mathrm{f}$ & $2.78 \mathrm{c}-\mathrm{g}$ & $3.03 \mathrm{~B}$ \\
\hline MO 3\% + V 4.5\% & $2.67 \mathrm{c}$ & $2.93 \mathrm{bc}$ & $3.07 \mathrm{a}-\mathrm{c}$ & $2.89 \mathrm{~B}$ & $2.54 \mathrm{e}-\mathrm{h}$ & $2.43 \mathrm{e}-\mathrm{h}$ & $3.04 \mathrm{a}-\mathrm{f}$ & $2.67 \mathrm{~B}$ \\
\hline Control & $3.06 \mathrm{~A}$ & $3.20 \mathrm{~A}$ & $3.11 \mathrm{~A}$ & - & $2.64 \mathrm{~B}$ & $3.22 \mathrm{~A}$ & $2.88 \mathrm{~B}$ & - \\
\hline
\end{tabular}

$-\mathrm{MO}=$ mineral oil.

- H.C. = Hydrogen cyanamide

Mean separation within treatments, dates of spraying of the pomegranate trees and for their interaction according to L.S.D. at 0.05 level.

Table (15): Mean values of Hydrogen cyanamide and mineral oil application alone or in combination with different concentrations and dates on the total soluble solids (TSS) percentage of Manfalouty pomegranate during 2014and 2015 seasons.

\begin{tabular}{|l|c|c|c|c|c|c|c|c|}
\hline \multirow{2}{*}{ Spraying dates } & \multicolumn{4}{|c|}{$\mathbf{2 0 1 4}$} & \multicolumn{3}{c|}{$\mathbf{2 0 1 5}$} \\
\cline { 2 - 10 } Treatments & $\mathbf{1}^{\text {st }}$ Jan. & $\mathbf{1 5}^{\text {th }}$ Jan. & $\mathbf{1}^{\text {st }}$ Feb. & Mean & $\mathbf{1}^{\text {st }}$ Jan. & $\mathbf{1 5}^{\text {th }}$ Jan. & $\mathbf{1}^{\text {st }}$ Feb. & Mean \\
\hline Control & $12.70 \mathrm{j}$ & $12.70 \mathrm{j}$ & $12.70 \mathrm{j}$ & $12.70 \mathrm{E}$ & $11.87 \mathrm{~m}$ & $11.87 \mathrm{~m}$ & $11.87 \mathrm{~m}$ & $11.87 \mathrm{~F}$ \\
\hline M.O 3\% & $13.90 \mathrm{gh}$ & $13.57 \mathrm{i}$ & $13.77 \mathrm{hi}$ & $13.75 \mathrm{D}$ & $12.87 \mathrm{k}$ & 12.671 & 12.571 & $12.70 \mathrm{E}$ \\
\hline H.C. 1.5\% & $14.13 \mathrm{c}-\mathrm{g}$ & $13.77 \mathrm{hi}$ & $13.60 \mathrm{i}$ & $13.83 \mathrm{CD}$ & $13.13 \mathrm{j}$ & $13.03 \mathrm{jk}$ & $12.90 \mathrm{k}$ & $13.02 \mathrm{DE}$ \\
\hline H.C. 3\% & $14.20 \mathrm{c}-\mathrm{f}$ & $14.07 \mathrm{e}-\mathrm{g}$ & $13.97 \mathrm{fgh}$ & $14.08 \mathrm{BC}$ & $13.40 \mathrm{hi}$ & $13.33 \mathrm{i}$ & $13.03 \mathrm{jk}$ & $13.25 \mathrm{D}$ \\
\hline H.C. 4.5\% & $14.40 \mathrm{bc}$ & $14.13 \mathrm{c}-\mathrm{g}$ & $14.33 \mathrm{~b}-\mathrm{e}$ & $14.29 \mathrm{AB}$ & $13.87 \mathrm{e}$ & $13.67 \mathrm{fg}$ & $13.53 \mathrm{gh}$ & $13.69 \mathrm{C}$ \\
\hline MO 3\% + H.C. 1.5\% & $14.37 \mathrm{bcd}$ & $14.27 \mathrm{c}-\mathrm{e}$ & $14.17 \mathrm{c}-\mathrm{g}$ & $14.27 \mathrm{AB}$ & $14.18 \mathrm{~cd}$ & $13.93 \mathrm{e}$ & $13.67 \mathrm{fg}$ & $13.93 \mathrm{BC}$ \\
\hline MO 3\% + H.C. 3\% & $14.57 \mathrm{~b}$ & $14.23 \mathrm{c}-\mathrm{f}$ & $14.10 \mathrm{~d}-\mathrm{g}$ & $14.30 \mathrm{AB}$ & $14.37 \mathrm{~b}$ & $14.13 \mathrm{~d}$ & $13.80 \mathrm{ef}$ & $14.10 \mathrm{AB}$ \\
\hline MO 3\% + V 4.5\% & $15.07 \mathrm{a}$ & $14.27 \mathrm{c}-\mathrm{e}$ & $14.27 \mathrm{c}-\mathrm{e}$ & $14.54 \mathrm{~A}$ & $15.00 \mathrm{a}$ & $14.33 \mathrm{bc}$ & $14.00 \mathrm{de}$ & $14.44 \mathrm{~A}$ \\
\hline Control & $14.17 \mathrm{~A}$ & $13.88 \mathrm{~B}$ & $13.86 \mathrm{~B}$ & - & $13.59 \mathrm{~A}$ & $13.37 \mathrm{~B}$ & $13.17 \mathrm{C}$ & - \\
\hline
\end{tabular}

- MO = mineral oil.

- H.C. $=$ Hydrogen cyanamide

Mean separation within treatments, dates of spraying of the pomegranate trees and for their interaction according to L.S.D. at 0.05 level.

Table (16): Mean values of Hydrogen cyanamide and mineral oil application alone or in combination with different concentrations and dates on acidity percentage of Manfalouty pomegranate during 2014 and 2015 seasons.

\begin{tabular}{|l|c|c|c|c|c|c|c|c|}
\hline \multirow{2}{*}{ Spraying dates } & \multicolumn{4}{c|}{$\mathbf{2 0 1 4}$} & \multicolumn{4}{c|}{$\mathbf{2 0 1 5}$} \\
\cline { 2 - 10 } Treatments & $\mathbf{1}^{\text {st }}$ Jan. & $\mathbf{1 5}^{\text {th }}$ Jan. & $\mathbf{1}^{\text {st }}$ Feb. & Mean & $\mathbf{1}^{\text {st }}$ Jan. & $\mathbf{1 5}^{\text {th }}$ Jan. & $\mathbf{1}^{\text {st }}$ Feb. & Mean \\
\hline Control & $2.03 \mathrm{a}$ & $2.03 \mathrm{a}$ & $2.03 \mathrm{a}$ & $2.03 \mathrm{~A}$ & $1.81 \mathrm{a}$ & $1.81 \mathrm{a}$ & $1.81 \mathrm{a}$ & $1.81 \mathrm{~A}$ \\
\hline M.O 3\% & $1.67 \mathrm{~b}-\mathrm{e}$ & $1.69 \mathrm{~b}-\mathrm{e}$ & $1.68 \mathrm{~b}-\mathrm{e}$ & $1.68 \mathrm{~B}-\mathrm{D}$ & $1.44 \mathrm{c}-\mathrm{e}$ & $1.44 \mathrm{~cd}$ & $1.55 \mathrm{~b}$ & $1.48 \mathrm{~B}$ \\
\hline H.C. 1.5\% & $1.73 \mathrm{bc}$ & $1.77 \mathrm{~b}$ & $1.78 \mathrm{~b}$ & $1.76 \mathrm{~B}$ & $1.41 \mathrm{c}-\mathrm{f}$ & $1.42 \mathrm{c}-\mathrm{f}$ & $1.48 \mathrm{bc}$ & $1.44 \mathrm{BC}$ \\
\hline H.C. 3\% & $1.66 \mathrm{~b}-\mathrm{e}$ & $1.71 \mathrm{~b}-\mathrm{d}$ & $1.72 \mathrm{bc}$ & $1.70 \mathrm{BC}$ & $1.37 \mathrm{~d}-\mathrm{g}$ & $1.43 \mathrm{c}-\mathrm{e}$ & $1.44 \mathrm{c}-\mathrm{e}$ & $1.41 \mathrm{~B}-\mathrm{D}$ \\
\hline H.C. 4.5\% & $1.55 \mathrm{ef}$ & $1.55 \mathrm{ef}$ & $1.57 \mathrm{~d}-\mathrm{f}$ & $1.56 \mathrm{D}$ & $1.31 \mathrm{~g}-\mathrm{i}$ & $1.38 \mathrm{~d}-\mathrm{g}$ & $1.44 \mathrm{c}-\mathrm{e}$ & $1.38 \mathrm{C}-\mathrm{E}$ \\
\hline MO 3\% + H.C. 1.5\% & $1.57 \mathrm{~d}-\mathrm{f}$ & $1.61 \mathrm{c}-\mathrm{f}$ & $1.61 \mathrm{c}-\mathrm{f}$ & $1.60 \mathrm{CD}$ & $1.27 \mathrm{hi}$ & $1.36 \mathrm{~d}-\mathrm{f}$ & $1.40 \mathrm{c}-\mathrm{f}$ & $1.34 \mathrm{DE}$ \\
\hline MO 3\% + H.C. 3\% & $1.33 \mathrm{~h}$ & $1.37 \mathrm{gh}$ & $1.48 \mathrm{fg}$ & $1.39 \mathrm{E}$ & $1.27 \mathrm{hi}$ & $1.31 \mathrm{~g}-\mathrm{i}$ & $1.35 \mathrm{e}-\mathrm{h}$ & $1.31 \mathrm{E}$ \\
\hline MO 3\% + V 4.5\% & $1.16 \mathrm{i}$ & $1.27 \mathrm{hi}$ & $1.33 \mathrm{~h}$ & $1.25 \mathrm{~F}$ & $1.26 \mathrm{i}$ & $1.31 \mathrm{~g}-\mathrm{i}$ & $1.34 \mathrm{f}-\mathrm{i}$ & $1.30 \mathrm{E}$ \\
\hline Control & $1.59 \mathrm{~B}$ & $1.63 \mathrm{AB}$ & $1.65 \mathrm{~A}$ & - & $1.39 \mathrm{C}$ & $1.43 \mathrm{~B}$ & $1.48 \mathrm{~A}$ & - \\
\hline
\end{tabular}

- MO = mineral oil. $\quad$ - H.C. = Hydrogen cyanamide

Mean separation within treatments, dates of spraying of the pomegranate trees and for their interaction according to L.S.D. at 0.05 level.

Data in Table (17) as regard to the Vitamin C percentage data showed that the highest significant values were achieved by $1^{\text {st }}$ January $\mathrm{x}$ MO3\% + H.C. $4.5 \%$ (20.20 and 18.90\%) in both growing seasons, respectively compared to the other treatments. The results are in harmony with those obtained by Naderi (2014) who indicated that the highest amount of vitamin $\mathrm{C}$ belonged to the 
Table (17): Mean values of Hydrogen cyanamide and mineral oil application alone or in combination with different concentrations and dates on Vitamin $\mathrm{C}(\mathrm{mg} / 100 \mathrm{ml}$ juice) of Manfalouty pomegranate during 2014and 2015 growing seasons.

\begin{tabular}{|l|c|c|c|c|c|c|c|c|}
\hline \multirow{2}{*}{ Spraying dates } & \multicolumn{4}{|c|}{$\mathbf{2 0 1 4}$} & \multicolumn{4}{c|}{2015} \\
\cline { 2 - 9 } Treatments & $\mathbf{1}^{\text {st }}$ Jan. & $\mathbf{1 5}^{\text {th }}$ Jan. & $\mathbf{1}^{\text {st }}$ Feb. & Mean & $\mathbf{1}^{\text {st }}$ Jan. & $\mathbf{1 5}^{\text {th }}$ Jan. & $\mathbf{1}^{\text {st }}$ Feb. & Mean \\
\hline Control & $11.32 \mathrm{i}$ & $11.32 \mathrm{i}$ & $11.32 \mathrm{i}$ & $11.32 \mathrm{E}$ & $8.40 \mathrm{e}-\mathrm{h}$ & $8.40 \mathrm{e}-\mathrm{h}$ & $8.40 \mathrm{e}-\mathrm{h}$ & $8.40 \mathrm{D}$ \\
\hline M.O 3\% & $12.43 \mathrm{hi}$ & $12.65 \mathrm{~g}-\mathrm{i}$ & $12.21 \mathrm{hi}$ & $12.43 \mathrm{DE}$ & $13.13 \mathrm{bc}$ & $11.55 \mathrm{~b}-\mathrm{e}$ & $7.35 \mathrm{~h}$ & $10.68 \mathrm{BC}$ \\
\hline H.C. 1.5\% & $12.88 \mathrm{fghi}$ & $12.88 \mathrm{f}-\mathrm{i}$ & $12.21 \mathrm{hi}$ & $12.66 \mathrm{DE}$ & $12.81 \mathrm{bc}$ & $7.88 \mathrm{f}-\mathrm{h}$ & $7.46 \mathrm{gh}$ & $9.38 \mathrm{CD}$ \\
\hline H.C. 3\% & $14.21 \mathrm{c}-\mathrm{h}$ & $13.76 \mathrm{~d}-\mathrm{i}$ & $13.10 \mathrm{e}-\mathrm{i}$ & $13.69 \mathrm{CD}$ & $13.65 \mathrm{~b}$ & $8.19 \mathrm{f}-\mathrm{h}$ & $8.93 \mathrm{~d}-\mathrm{h}$ & $10.26 \mathrm{~B}-\mathrm{D}$ \\
\hline H.C. 4.5\% & $16.20 \mathrm{~b}-\mathrm{d}$ & $16.43 \mathrm{~b}-\mathrm{d}$ & $15.76 \mathrm{~b}-\mathrm{e}$ & $16.13 \mathrm{AB}$ & $10.19 \mathrm{c}-\mathrm{h}$ & $10.29 \mathrm{c}-\mathrm{h}$ & $8.40 \mathrm{e}-\mathrm{h}$ & $9.63 \mathrm{CD}$ \\
\hline MO 3\% + H.C. 1.5\% & $15.99 \mathrm{~b}-\mathrm{d}$ & $15.32 \mathrm{~b}-\mathrm{g}$ & $14.65 \mathrm{c}-\mathrm{h}$ & $15.32 \mathrm{BC}$ & $10.92 \mathrm{~b}-\mathrm{f}$ & $7.98 \mathrm{f}-\mathrm{h}$ & $8.40 \mathrm{e}-\mathrm{h}$ & $9.10 \mathrm{CD}$ \\
\hline MO 3\% + H.C. 3\% & $17.76 \mathrm{ab}$ & $16.43 \mathrm{~b}-\mathrm{d}$ & $15.54 \mathrm{~b}-\mathrm{f}$ & $16.58 \mathrm{AB}$ & $18.06 \mathrm{a}$ & $8.51 \mathrm{e}-\mathrm{h}$ & $9.98 \mathrm{c}-\mathrm{h}$ & $12.18 \mathrm{AB}$ \\
\hline MO 3\% + V 4.5\% & $20.20 \mathrm{a}$ & $17.98 \mathrm{ab}$ & $16.65 \mathrm{bc}$ & $18.28 \mathrm{~A}$ & $18.90 \mathrm{a}$ & $10.71 \mathrm{~b}-\mathrm{g}$ & $11.76 \mathrm{~b}-\mathrm{d}$ & $13.79 \mathrm{~A}$ \\
\hline Control & $15.12 \mathrm{~A}$ & $14.60 \mathrm{AB}$ & $13.93 \mathrm{~B}$ & - & $13.26 \mathrm{~A}$ & $9.19 \mathrm{~B}$ & $8.83 \mathrm{~B}$ & - \\
\hline
\end{tabular}

- $\mathrm{MO}=$ mineral oil.

- H.C. = Hydrogen cyanamide

Mean separation within treatments, dates of spraying of the pomegranate trees and for their interaction according to L.S.D. at 0.05 level.

combination treatment of Volk oil + Hydrogen cyanamide. Gehan et al. (2011) and Sabry et al. (2011) added that, the combination treatment of Jasmine oil + Hydrogen cyanamide resulted in high fruit quality.

\section{Conclusion}

This study suggested that treatment with mineral oil plus Hydrogen cyanamide "Hydrogen cyanamide" (MO 3\% + H.C. 4.5\%) treated on the $1^{s t}$ of January is considerd as useful technology for producing early and high quality Manfalouty pomegranate under Assiut climatic conditions.

\section{REFERENCES}

Abdel All E. H. A. (2007). Effect of fruit thinning and spraying with some chelated elements and calcium on yield and fruit quality of Manfalouty pomegranate. Thesis M. Sc., Fac. of Agric., Minia Univ., Egypt.

A.O.A.C. (1985). Associate of Official Analytical Chemists. Official Methods of Analysis $14^{\text {th }}$ ed., washington DC., USA.

A.O.A.C. (2000). Associate of Official Analytical Chemists. Official Methods of Analysis $7^{\text {th }}$ ed. Washington D.C., USA.

Ahmed F. F., Ibrahim H. I. M., Abada M. A. M. and Osman M.M.M. (2014). Using plant extracts and chemical rest breakages for breaking bud dormancy and improving productivity of superior grapevines growing under hot climates. World Rural Observ, 6(3):8-18.

Doorenbos J. (1953). Review of literature on dormancy in buds of woody plants. Land Bhoogesh. Wagenin, 53: 1-23.
Duncan B.D. (1955). Multiple test range and multiple F tests. Biometries.11-142.

Elloumi O., Ghrab M., Kessentini H. and Mimoun M.B. (2013). Chilling accumulation effects on performance of pistachio trees cv. Mateur in dry and warm area climate. Sci. Hort., 159:80-87.

El-Sharkawy S. M. M. and Osman I. M. S. (2009). Effect of foliar applications of some growth regulators on flowering, fruit production and quality of Wichita and Western Schley pecan cultivars. Egypt. J. Hort., 36(1):29-46.

Erez A., Rignwald S. and Yablowitz Z. (1993). New means to break bud rest and advance bloom in apple and peach. ISHS, Sym. on (TZFTS) Cairo, Egypt, Abst, p: 33.

Gehan H. S., Hanaa A. E. and Ansam S. A. (2011). A study on using jasmine oil as a breaking bud dormancy for flame seedless grapevines. Report and Opinion, 3(2):4856.

Georg A.R., Nissen R.J. and Baker J.A. (1988). Effect of hydrogen cyanamide in manipulating budburst and advancing fruit maturity of table grapes in Southeastern Queensland's. Aust. J. Exp. Agric., 28: 533-538.

Haggag M. N., Ezz T. M. and El-Kobbia A.M. (1999). Bud break, yield, fruit quality and enzyme activity of Banati pomegranate trees in relation to Hydrogen cyanamide spray. Alexandria J. Agric. Res., 44(2):175-184.

Hegazi A. A. (2012). Effects of Some Dormancy Breaking Agents on Flowering, Fruiting and Fruit Characteristics of 'Canino' 
Apricot Cultivar. World J. Agric. Sci., 8 (2): 169-173.

Hsia C. L., Luh B. S. and Chickester C.O. (1965). Anthocyanin in freestone peaches. J. food sci., 30, 5-12.

Melgarejo P., Martínez J. J., Hernández F., Martínez R., Legua P., Oncina R. and Martínez-Murcia A. (2009). Cultivar identification using 18S-28S rDNA intergenic spacer-RFLP in pomegranate (Punica granatum L.). Sci. Hortic., 120 (4): 500-503.

Mofeed A.S. (2009). Effect of conversion to organic farming on yield, fruits and oil quality of olive. Ph. D. Thesis Faculty of Agriculture, Ain Shams University, Egypt.

Naderi A. (2014). The study of different treatments effect on the amount of vitamin $\mathrm{C}$ in overcoming the grapevine buds dormancy. Indian J. Fund. Appl.Life Sci., 4(2):474-479.

Ozguven A.I., Yilmaz M., Yilmaz C. and Rehber, Y. (2009). The adaptation of different pomegranate cultivars to the ecological conditions of Northern Cyprus. Acta hort. 818, March 2009: International Sympoium on pomegranate and Minor Mediterranean Fruits, Northern Cyprus.

Panwar S., Desai U. T. and Choudhary S. M.
(1994). Effect of pruning on physiological disorder in pomegranate. Ann. Arid Zone, 33: 83-84.

Sabry G. H., El-Helw H. A. and Abd El-Rahman A. S. (2011). A study on using Jasmine Oil as a breaking bud dormancy for Flame seedless grapevines. Report and Opinion, 3(2):48-56.

Sawarsan M. R., El-Bolok K. T. and Abou-Taleb S. A. (2011). A comparative study on some pomegranate cultivars under the ecological conditions of Souhag Governorate, Agric. Res., J. Suez Canal University, 11 (12): 101-106.

Seif El-Yazal M. A., Seif El-Yazal S.A. and Rady M. M. (2014). Exogenous dormancy-breaking substances positively change endogenous phytohormones and amino acids during dormancy release in 'Anna' apple trees. Plant Growth Regul., 72:211-220.

Singh S. (1995). Pomegranate. In: Commercial Fruits, pp. 225-233. Kalyani Publisher, Ludhiana. Indian.

Snedecor G.W. and Cochran W.G. (1972). Statistical Methods. $7^{\text {th }}$ Ed. The Iowa State Univ., Press Ames, Iowa, U.S.A., p.593.

Winton A. H. and Winton K.B. (1945). Analysis of food. Wiley, New York, USA., p 572. 


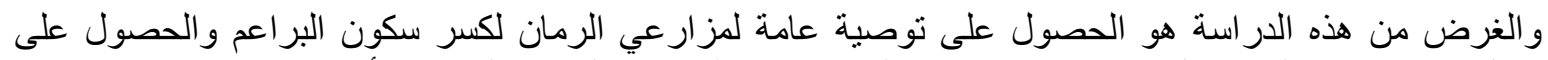

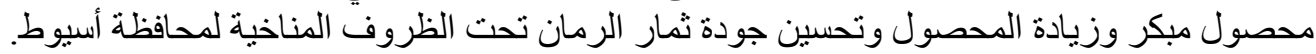

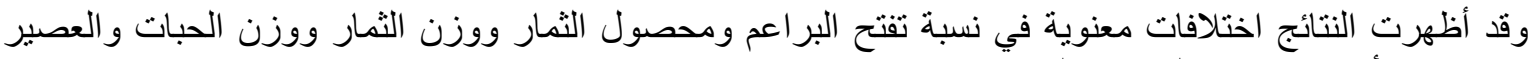

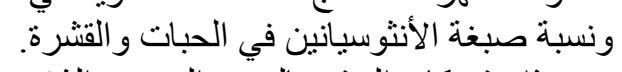

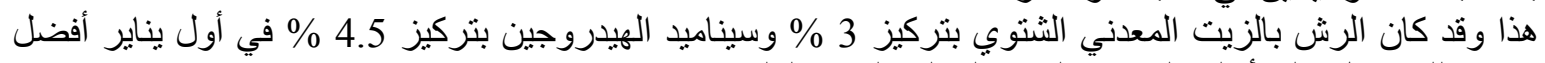

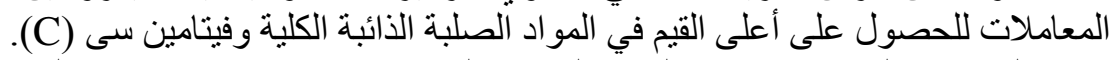

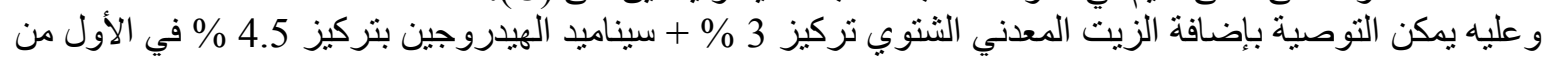

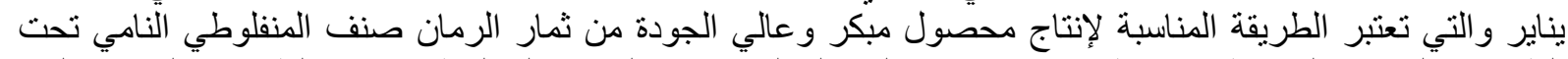

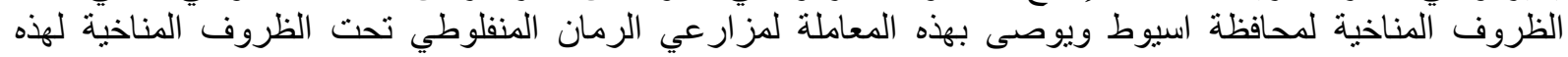

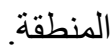
المجلة العلمية لكلية الزراعة - جامعة القاهرة ـ المجلا (68) العدد الثالث (يوليو 2017): 331-319. 